University of San Diego

Digital USD

Spring 5-25-2018

\title{
The temporal and spatial dynamics of larval supply, settlement, and adult populations of Chthamalus fissus within the La Jolla, California rocky intertidal
}

Catharine Hargenrader

University of San Diego

Follow this and additional works at: https://digital.sandiego.edu/theses

Part of the Marine Biology Commons, and the Population Biology Commons

\section{Digital USD Citation}

Hargenrader, Catharine, "The temporal and spatial dynamics of larval supply, settlement, and adult populations of Chthamalus fissus within the La Jolla, California rocky intertidal" (2018). Theses. 30. https://digital.sandiego.edu/theses/30

This Thesis: Open Access is brought to you for free and open access by the Theses and Dissertations at Digital USD. It has been accepted for inclusion in Theses by an authorized administrator of Digital USD. For more information, please contact digital@sandiego.edu. 


\title{
UNIVERSITY OF SAN DIEGO
}

\author{
San Diego
}

The temporal and spatial dynamics of larval supply, settlement, and adult populations of Chthamalus fissus within the La Jolla, California rocky intertidal

A thesis submitted in partial satisfaction of the requirements for the degree of Master of Science in Marine Science

By

Catharine Shaw Hargenrader

Thesis Committee

Nathalie Reyns, Ph.D., Chair

Jesús Pineda, Ph.D.

Jennifer Prairie, Ph.D. 
The thesis of Catharine Shaw Hargenrader is approved by:

Nathalie Reyns, Ph.D., Thesis Committee Chair University of San Diego

Jesús Pineda, Ph.D., Thesis Committee Member Woods Hole Oceanographic Institution

Jennifer C. Prairie, Ph.D., Thesis Committee Member University of San Diego

University of San Diego

San Diego

2018 
Copyright $(9) 2018$

Catharine Shaw Hargenrader

All Rights Reserved 


\section{ACKNOWLEDGEMENTS}

First, I must thank my advisor and committee chair, Dr. Nathalie Reyns who was an incredible mentor these past four-years. She provided a plethora of opportunity for me to genuinely learn the scientific method from the initial conception of a research theory through the final product of a research article. Through these opportunities she allowed me to take on new roles as a scientific diver, a field and lab leader for her larger grant, and much more. In the ups and downs of graduate school I can confidently say she helped me maintain my enthusiasm for marine ecology and develop into a stronger science professional. In addition, I would like to thank the rest of my thesis committee Dr. Jesús Pineda

and Dr. Jennifer Prairie for their support and feedback throughout the processes of developing and finalizing my thesis.

It is also important for me to thank our entire research team who worked on the various National Science Foundation grants these past four years under Dr. Nathalie Reyns, Dr. Jesús Pineda, and Dr. Steven Lentz. There was a long list of staffers on these projects and so I will highlight a few starting with Diana Fontaine who was an invaluable partner during two years of daily field work and countless hours of sample processing and lab upkeep. Additionally, thank you to Jamie Irving the first field technician under these NSF grants who constructed the larval traps used for my research and assisted in the finalizing of my adult survey protocols. Finally thank you tremendously to Anthony Basilio who served as a tremendous asset to the overall project, but for me was the first to welcome me to USD and helped me plow through the microscope sorting for a portion of my 
larval supply samples. Thank you tremendously to additional individuals who assisted in field collections, especially adult surveys, including Whitney Sears, Colin Gaylord, Meredith Meyers, Jake Brouker, Haley Cahill, and Nima Farchadi, etc.

My thesis project would not have been possible without the USD Environmental and Ocean Sciences faculty, staff, and graduate student community. I am grateful for the monetary support I have received from the department throughout the years, the assistance with field and lab challenges provided by varying members of the faculty and staff, and most importantly the community of encouragement and support which our graduate students worked hard to build. Specifically, thank you to Dr. Suzanne Walther and Russ Harrel who allowed me to utilize their GPS system to mark within-site locations and their associated elevations and also mentored me through the process of using this system. I would be remiss if I did not especially acknowledge Joy Shapiro, Thais Fournier, Laura Schwebel, and Elizabeth Johnston who made this experience one of a kind and filled with memories from start to finish! In my time at USD I was fortunate to complete my elective at Friday Harbor Labs - University of Washington and I would like to also thank my fellow students, professor Dr. Megan Dethier, and dive instructor Pema Kitaeff for helping me build on my knowledge of the scientific process as it relates to inter and sub-tidal ecology. Lastly, and most importantly I would like to thank my family and boyfriend Donovan Sanchez who have supported, encouraged, and provided constructive feedback through all the highs and lows of this experience. Thank 
you to my family for always encouraging me to dream big and push through no matter how tired I was after late night field excursions or how overwhelmed I felt with sample processing. And a huge thank you to Donovan who came into my life and helped me remember that I can defy the odds and build a career in marine science beyond anything I can imagine!

Lastly, I would like to dedicate my thesis to two men who have helped shape my passion for science and encourage me to broaden the scope of what it means to be a scientist, my undergraduate advisor Dr. Kevin Scott Beach and my grandfather Louis Hargenrader. 


\section{TABLE OF CONTENTS}

LIST OF TABLES pp. ix. $-\mathrm{x}$.

CHAPTER 1: Literature Review and Introduction p. 3

Rocky intertidal communities. pp. $3-4$

Barnacle life history pp. $4-5$

Benthic community ecology pp. $5-6$

Post-settlement factors pp. $6-7$

Pre-settlement factors pp. $7-10$

Main objectives pp. $10-12$

Figures and Captions pp. $14-17$

CHAPTER 2: Decoupling of larval supply and settlement and the potential habitat factors which influence settlement of Chthamalus fissus across space and time in the rocky intertidal of La Jolla, California, USA........................... p. 18

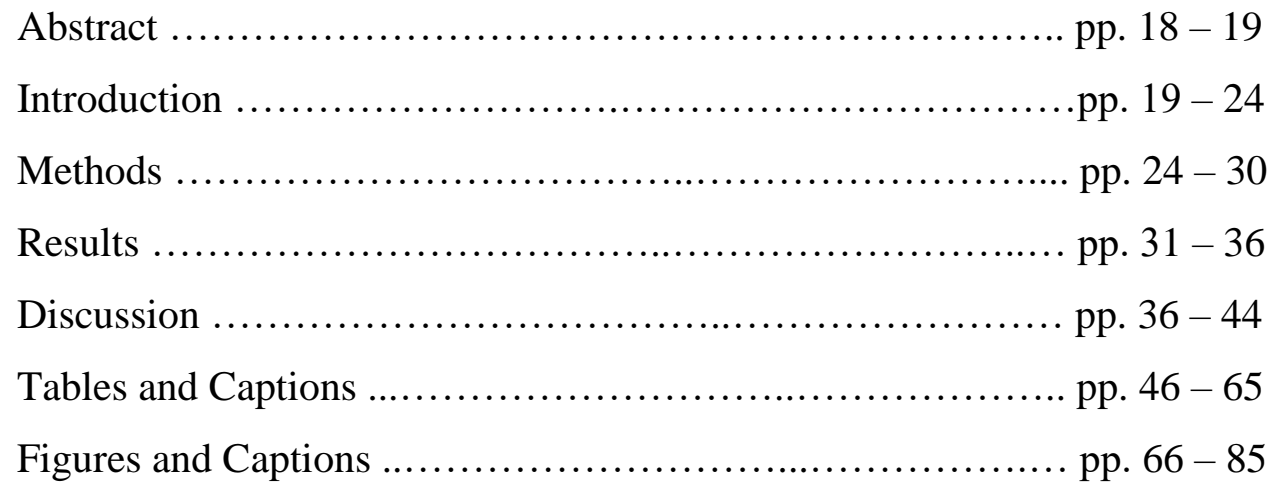


CHAPTER 3: General Thesis Conclusions

pp. $86-89$

LITERATURE CITED

pp. $91-107$

APPENDIX A: Larval supply equipment ....................... pp. $109-110$

APPENDIX B: Trap versus plate elevations .....................pp. $111-112$

APPENDIX C: Settlement equipment ......................... pp. $113-114$

APPENDIX D: Adult/habitat survey set-up ....................... pp. 115 - 116

APPENDIX E: Hydrodynamics and larval supply ............... pp. $117-118$

APPENDIX F: Wave height versus sediment influx ................ pp. $119-120$ 


\section{LIST OF TABLES}

CHAPTER 2: Decoupling of larval supply and settlement and the potential habitat factors which influence settlement of Chthamalus fissus in the rocky intertidal of La Jolla, California, USA

Table 1. Averages ( \pm SE) and proportions of barnacle larvae (traps for larval supply) and settlers (plates for settlement) during summer 2014 and summer 2015 pp. $50-51$

Table 2. Average rank for settlement by location for Spring-Summer 2014 (June $16^{\text {th }}$-July $16^{\text {th }}, 2014$ ) pp. $52-53$

Table 3. Average rank for settlement by location for Spring-Summer 2015a (April 24 ${ }^{\text {th }}$-June $5^{\text {th }}, 2015$ ) pp. $54-55$

Table 4. Average rank for settlement by location for Spring-Summer 2015 b (June $6^{\text {th }}$-August $2^{\text {nd }}, 2015$ ) pp. $56-57$

Table 5. Chthamalus fissus months for settlement plate collection and adult population/habitat surveys from April 2014 to December 2016 pp. $58-59$

Table 6. Model selection to quantify the relationship between monthlyaveraged settlement of Chthamalus fissus and percentage of habitat cover, $\mathrm{n}=21$ months pp. $60-61$

Table 7. Model selection to quantify the relationship between monthlyaveraged percent free space and live barnacles, dead barnacles, and algae, $\mathrm{n}=21$ months pp. $62-63$

Table 8. Ranked relative importance of factors explaining the variability in percent free space from the Akaike weights in Table 7, $\mathrm{n}=21$ months pp. $64-65$ 
Table 9. Significance values ( $\mathrm{p}<0.05$ are in bold) comparing Chthamalus fissus settlement across pairs for locations 3-14 (April 24 $4^{\text {th }}, 2014$

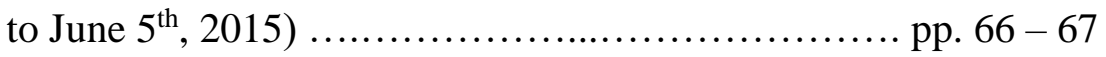

Table 10. Significance values ( $\mathrm{p}<0.05$ are in bold) comparing Chthamalus fissus settlement across pairs for locations 1-14 (June $6^{\text {th }}, 2015$ to December $\left.15^{\text {th }}, 2015\right) \ldots \ldots \ldots \ldots \ldots .$. pp. $68-69$ 


\section{LIST OF FIGURES}

CHAPTER 1: Literature Review and Introduction

Figure 1. General life history of barnacle species from development in the coastal ocean through recruitment in the rocky intertidal

pp. $14-15$

Figure 2. Processes influencing recruitment in bottom-dwelling species, as previously described in Pineda (2000)

pp. $16-17$

CHAPTER 2: Decoupling of larval supply and settlement and the potential habitat factors which influence settlement of Chthamalus fissus in the rocky intertidal of La Jolla, California, USA

Figure 1. Study site within the southern California region of Bird Rock, La Jolla; including where larval supply, settlement, and adult populations were measured ..........................pp. $70-71$

Figure 2. Time series for Chthamalus fissus larval supply and settlement for 2014, 2015a, and 2015b pp. $72-73$

Figure 3. Average transformed Chthamalus fissus larval supply versus average transformed Chthamalus fissus settlement by location for 2014, 2015a, and 2015b pp. $74-75$

Figure 4. Average proportion of Chthamalus fissus settlement from 2014 to 2016 by plate with respect to elevation and distance to water pp. $76-77$

Figure 5. Monthly-averaged Chthamalus fissus settlement compared to habitat cover characteristics (i.e. free space, live barnacles, dead barnacles, algae) from December of 2014 to December of 2016, $\mathrm{n}=21$ months pp. $78-79$ 
Figure 6. Monthly-averaged Chthamalus fissus settlement versus free space by locations 1 to 14 from December 2014 to December 2016, $\mathrm{n}=21$ months pp. $80-81$

Figure 7. Log-transformed monthly-averaged Chthamalus fissus settlement versus monthly-averaged percent free space across all plates, $\mathrm{n}=21$ months pp. $82-83$

Figure 8. Monthly-averaged percent free space compared to additional habitat characteristics of live barnacle, dead barnacle, and algae cover, $\mathrm{n}=21$ months pp. $84-85$

Figure 9. Average Chthamalus fissus settlement \pm SE, average proportion of settlement \pm SE for 12-plate locations $(n=217$ days per plate) versus 14-plate locations $(n=156$ days $)$, further comparing average proportion of settlement \pm SE per plate in 2014 ( $n=173$ days) versus in $2015(n=200$ days) pp. $86-87$

Figure 10. Average rank of Chthamalus fissus settlement for 12 plates and 14 plates pp. $88-89$ 


\begin{abstract}
The role of post-settlement processes in benthic invertebrate recruitment dynamics has been well established; however, more recently, studies have been resolving the pre-settlement processes and environmental variables that may shape initial settlement. We examined the major space occupying barnacle Chthamalus fissus to determine the spatial and temporal dynamics of settlement in relation to larval supply, adult populations, and habitat characteristics (including elevation as a proxy for immersion, proximity to water's edge, and the availability of free space) within the La Jolla, CA rocky intertidal. With respect to habitat characteristics, we investigated the influence of available free space on the dynamics of settlement through intensification, defined as a higher concentration of settlers with less available free space. Six larval traps were deployed daily to quantify larval supply, 12-14 PVC plates were deployed daily or weekly to quantify settlement, and 12-14 surveys were conducted during new moon periods every month to quantify adults and habitat cover. There was temporal variability, specifically with high rates of settlement, and high percentages of adult populations and habitat cover occurring mainly in the summer periods. Spatially, of the 14 locations studied within the site, two locations exhibited some of the highest settlement rates when compared to larval supply or adults and habitat cover. There was a non-significant relationship between larval supply and settlement, suggesting that the environment played a more important role in shaping spatial and temporal population dynamics. Settlement, when compared with habitat cover, was primarily driven by available free space, which was
\end{abstract}


determined by live barnacle and algae cover. We observed the highest settlement when free space was lowest, demonstrating evidence of intensification within our site. These results suggest that in some cases habitat dynamics may play a more important role in shaping settlement than larval supply. Understanding the extent of this role may help to more holistically establish the dynamics that shape initial benthic invertebrate settlement. Therefore, understanding the role of the environment in shaping settlement dynamics of benthic invertebrates can help further inform the importance of rocky intertidal locations in contributing to coastal marine productivity and diversity. 


\section{CHAPTER 1:}

\section{LITERATURE REVIEW AND INTRODUCTION}

\section{Rocky intertidal communities}

Intertidal ecosystems are unique marine ecosystems given their diverse habitat structure and species richness (Scrosati and Heaven 2007, Zwerschke et al. 2013). They provide a transition from marine to terrestrial habitats with attachment and refuge for a multitude of organisms in the form of exposed cliffs, boulders, rubble, or wave-influenced rocky shelves (Brandon and Rokop 1985). Within these communities are various marine algal, gastropod, cephalopod, chordate, cnidarian, and arthropod species (Brandon and Rokop 1985, Newman 1989).

Predominant benthic invertebrates within rocky intertidal communities include barnacle species, which have long been used as model species in ecological studies (Connell 1961a, b, Connell 1970, Dayton 1971, Paine 1974, Lubchenco and Menge 1978). For this research, given their presence in southern California, our study focused on Chthamalus spp. (Chthamalus fissus). Individuals are common on rocks, pier pilings, and hard-shelled organisms along the west coast of North America from Alaska to Baja California. This species occupies higher regions in the intertidal than most due to its overlapping, exterior plate configuration allowing this organism to withstand longer periods of desiccation through controlled opening of the opercular valve (Barnes and Barnes 1957, Foster 1971). The periods of highest reproduction for Chthamalus spp. 
occur during the spring to fall months, with limited reproduction in the winter season (Hines 1979). All barnacle species undergo similar stages of development throughout their life history.

\section{Barnacle life history}

Barnacle species have a meroplanktonic life cycle, similar to other marine benthic invertebrates which include planktonic larvae and sessile, benthic adults (Alexander and Roughgarden 1996) (Figure 1). Through fertilization and the brood period, the population size is dependent on biological (e.g., size of the adults and food availability) and physical (e.g., temperature) factors (Hines 1978). First-stage larvae, the shield-shaped nauplii, are released into the water column, and are transported offshore through physical oceanographic processes. During naupliar development, the larvae undergo 6 stages of molting, and then develop into cyprid larvae (known as "the settling stage”) (Høeg and Møller 2006). Cyprids have the ability to manipulate their vertical position in the water column (Tapia et al. 2010). However, within the intertidal immediately prior to settlement, cyprids are limited to small-scale swimming or crawling on their first antennae across the substratum to test for suitable attachment locations (Høeg and Møller 2006).

Cyprid selection of a settlement site is determined through the physical availability of substrate for settlement (Gaines et al. 1985, Pineda 1994) coupled with the chemical detection of the presence of conspecifics and predators (Raimondi 1988). Once cyprids are competent to settle, the first antennae, containing cement glands, attach to the substrate and the cyprid undergoes 
metamorphosis becoming a juvenile barnacle. Juvenile barnacles steadily grow and mature over a period of weeks to months before reaching their adult size (Smith and Johnson 1996). Upon maturation, barnacles are an important biological component of the rocky intertidal serving as space occupiers and prey for predators including marine gastropods (e.g., periwinkle snails and whelks) (Brandon and Rokop 1985).

Benthic community ecology

Benthic ecology focuses on understanding how physical and biological characteristics shape the population dynamics of various benthic marine organisms. The rocky intertidal serves as a common location for the study of such dynamics given its diversity of benthic sessile invertebrates. Barnacles serve as a suitable model organism to understand how benthic invertebrate populations are established and structured within rocky intertidal communities. This suitability is due to their common presence throughout rocky intertidal regions worldwide.

Furthermore, their population dynamics can be tracked over time, through pre-settlement, settlement, and post-settlement processes. Factors influencing the establishment and subsequent structuring of benthic populations and communities within intertidal regions have often been separated into pre- and post-settlement processes (Paine 1966, Connell 1970, Pineda 1991, Alexander and Roughgarden 1996, Shanks 2005, Starczak et al. 2011). The aim of ecological research investigating the life histories of barnacles is to understand and resolve the factors that influence survival through reproduction and their impacts on population changes through time (Pineda et al. 2009). 


\section{Pre-settlement factors}

In recent decades, pre-settlement processes have become more heavily addressed in the scientific literature, with the aim of understanding the physical and biological factors influencing the planktonic larval stage of marine organisms as it pertains to their population structuring (Todd 1998, Starczak et al. 2011, Pfaff et al. 2015). Pre-settlement processes affect the abundance of larvae, their delivery to adult habitats, and their settlement within adult habitats (Gaines et al. 1985, Farrell et al. 1991, Hughes et al. 2000, Starczak et al. 2011, Hoffmann et al. 2012, Pfaff et al. 2015). Understanding the influence of pre-settlement processes on early barnacle life history stages is a complex subject in that larval supply to adult habitats, or its operational equivalent, larval abundance near settlement sites, is influenced by factors affecting larval pool size, transport, and settling behaviors (Connell 1985, Pineda 2000) (Figure 2).

Overall, the population dynamics of marine species with a planktonic larval stage such as barnacles, are strongly influenced by interactions (e.g., larval transport) with their physical environment. Larvae develop offshore and are part of a "larval pool". The larval pool may decrease in size due to either advection of larvae away from suitable habitats or through various physical transport processes transporting larvae to adult habitats (Farrell et al. 1991, Pineda 1991, Alexander and Roughgarden 1996, Connolly and Roughgarden 1998, Pineda et al. 2009, Tapía et al. 2010). A number of physical oceanographic features may function as larval transport mechanisms, including Stokes drift, wave events, and internal tidal bores (Pineda 2000, Gawarkiewicz et al. 2007). Upon arrival in the nearshore, larval 
behavior influences the choice for a settlement location, based on the ability of cyprids to manipulate their vertical position within the water column to be retained in coastal areas (Pineda et al. 2010). Overall, the cyprids which are retained within the rocky intertidal will potentially contribute to the adult population.

The fraction of cyprids from the larval pool transported via pre-settlement processes, which are available for potential settlement within a given rocky intertidal location, is termed larval supply. There are several small-scale, intraintertidal factors which influence larval settlement, the permanent adhesion on a hard substrate and metamorphosis of a cyprid to the juvenile stage. Settlement is the ecological interface linking pre- and post-settlement factors which culminates in the formation of adult populations (Pineda et al. 2009). During settlement, the microhydrodynamic conditions (the formation of microeddies along the shoreward faces of rocks creating small-scale currents within the rocky intertidal) coupled with the ability of cyprids to detect the chemical cues of their conspecifics given their gregarious nature, may influence the approximate location of a cyprid within the intertidal (Pawilk 1992, Pineda 1998, Pineda et al. 2009, Elbourne et al. 2011). Upon arrival within the intertidal, the amount of available substrate will influence the spatial area and temporal scale over which settlement will occur (Pineda 1994, Pineda and Caswell 1997, Pineda et al. 2010).

Events of intensification describe when less natural substrate is available for settlement, given the behavioral abilities of cyprids to search for suitable substrate, searching larvae will settle more intensively per unit area in the available substrate location (Pineda 1994, Pineda and Caswell 1997, Pineda et al. 2010). 
Events such as these are termed the intensification effect (Pineda 1994, Pineda and Caswell 1997). As a result of this effect, seasonal and spatial variation in substrate variability may cause variability in barnacle larval settlement, further leading to patchiness of newly settled barnacles from season to season (Caffey 1985, Pineda and Caswell 1997, Pineda et al. 2010). Additional studies have investigated the intensification effect; when settlement reaches above a certain threshold it becomes more highly dependent on availability of space rather than larval availability (Pineda 1994, Jenkins 2005). For example, if two locations receive equal abundances of larval supply, but one location has more free space than the other, this may alter the patterns of settlement among these two locations (Bertness et al. 1992, Pineda and Caswell 1997, Jenkins 2005, Pineda et al. 2010). Specifically, when less space is available, there is a higher concentration of settlers within this available space (Pineda 1994, Pineda \& Caswell 1997, von der Meden et al. 2012). By understanding the transition from larval supply to settlement and metamorphosis, we will better understand how larval input into an ecosystem modulates adult barnacle populations, and the overarching community processes within the intertidal (Alexander and Roughgarden 1996, Hughes et al. 2000, Jonsson et al. 2004).

\section{Post-settlement factors}

Research has also focused on identifying the post-settlement processes that impact juveniles and adults: predation, competition for space, disturbance by biotic and abiotic (e.g., desiccation via exposure to air) events, and positive interactions with the environment, including the space in which juvenile barnacles mature to 
adults and reproduce (Stephenson and Stephenson 1949, Connell 1961 a, b, Paine 1966, Connell 1970, Dayton 1971, Connell 1985) (Figure 1). Classic investigations have revealed the specificity with which the above-listed factors determine the upper and lower limits of benthic invertebrates, specifically barnacle species. For example, through in situ observations and caging experiments, Connell (1961 a, b) found physical factors set the upper limits and a combination of biotic factors set the lower limits for species distributions when comparing Chthamalus stellatus and Balanus balanoides. These studies laid the framework for understanding rocky intertidal patterns of vertical zonation. To extend this theory, Paine (1966) established the role of predation in alleviating the intensity of competition in setting a species' lower limit, through predator removal events which led to localized extinctions of benthic invertebrate species including outcompeted Balanus glandula. Alternatively, Wethey (1983) furthered understanding of the geographic and zonation boundaries of Balanus spp. and Chthamalus spp. Specifically, the upper limit of Balanus spp. is set according to where this species can withstand the stresses of desiccation (Wethey 1983).

Within the rocky intertidal, a suite of physical and biological factors influences the distributions of organisms across environmental gradients (Beukema and Flach 1995), which may impact the long-term sustainability of these ecosystems (Alexander and Roughgarden 1996). The upper limits of species distributions are commonly set by physical factors (i.e. tolerance to desiccation or heat), whereas the lower limits are commonly set by biological interactions (i.e. interspecific competition for space, selective predation, and tidal disturbance) 
(Connell 1961 a, b, Connell 1970). Post-settlement factors shape the dynamics of juvenile and adult barnacle populations and communities. However, these dynamics are influenced by the variability in recruitment of larvae across spatial and temporal time scales, tying these processes to pre-settlement processes (Connell 1985). Therefore, the impacts of pre- and post-settlement factors on shaping barnacle populations varies across time and space depending on the geographic location and physical parameters of a given ecosystem. Our study will focus on settlement and post-settlement factors with respect to their role in shaping rocky intertidal populations of barnacle species.

\section{Main objectives}

By studying the life history of barnacles from the larval stage through to development of adult populations, the interface between pre- and post-settlement processes can be further understood with respect to its role in structuring benthic invertebrate populations, specifically barnacles within the rocky intertidal (Pineda et al. 2009, Starczak et al. 2011). The spatial and temporal distribution of the life history stages of various barnacle species may help to extrapolate general life history patterns and distributions of other intertidal organisms with a two-phase meroplanktonic life cycle. In the past several decades studies investigating the role of larval input on the dynamics of rocky shore communities, known as "supply-side ecology" have increased in prevalence (Pineda et al. 2010). To understand the potentially non-linear relationship between larval supply, settlement, and adult populations, each factor must be studied separately and compared to the others to gain a comprehensive understanding of the life history of these marine 
invertebrates. The questions I sought to answer, focusing on Chthamalus spp. within the Bird Rock rocky intertidal of La Jolla, CA, are:

1. How do larval supply (\# of cyprids per trap per day), larval settlement (\# of cyprids and metamorphs per plate per day), and adult populations (\# of living versus dead barnacles) and habitat characteristics ( $\%$ free space per $\mathrm{cm}^{2}$ per month) vary temporally across a two year period?

- $\mathrm{H}_{0}$ : There will be no change in larval supply, larval settlement, and adult populations within seasons (spring-summer and fall-winter) across a two-year period.

2. How do larval supply (\# of cyprids per trap per day), larval settlement (\# of cyprids and metamorphs per plate per day), adult populations (\# of living versus dead barnacles), and habitat characteristics (\% free space per $\mathrm{cm}^{2}$ per month) vary spatially within the study site?

- $\mathrm{H}_{0}$ : There will be no change in larval supply, larval settlement, and adult populations within the study site.

a) Are there spatial differences with respect to larval supply (\# of cyprids per trap per day) and larval settlement (\# of cyprids and metamorphs per plate per day)? 
- $\mathrm{H}_{0}$ : Larval supply and larval settlement are not correlated with one another.

b) If there are intra-site differences in larval supply (\# of cyprids per trap per day) and larval settlement (\# of cyprids and metamorphs per plate per day), how do they relate to habitat suitability with respect to \% free space?

- $\mathrm{H}_{0}$ : There is no association between larval supply, larval settlement, and $\%$ available free space within the study site. 


\section{CHAPTER 1 FIGURES}


Figure 1. General life history of barnacle species from development in the coastal ocean through recruitment in the rocky intertidal (Hines 1978, Pechenik et al. 1998). 


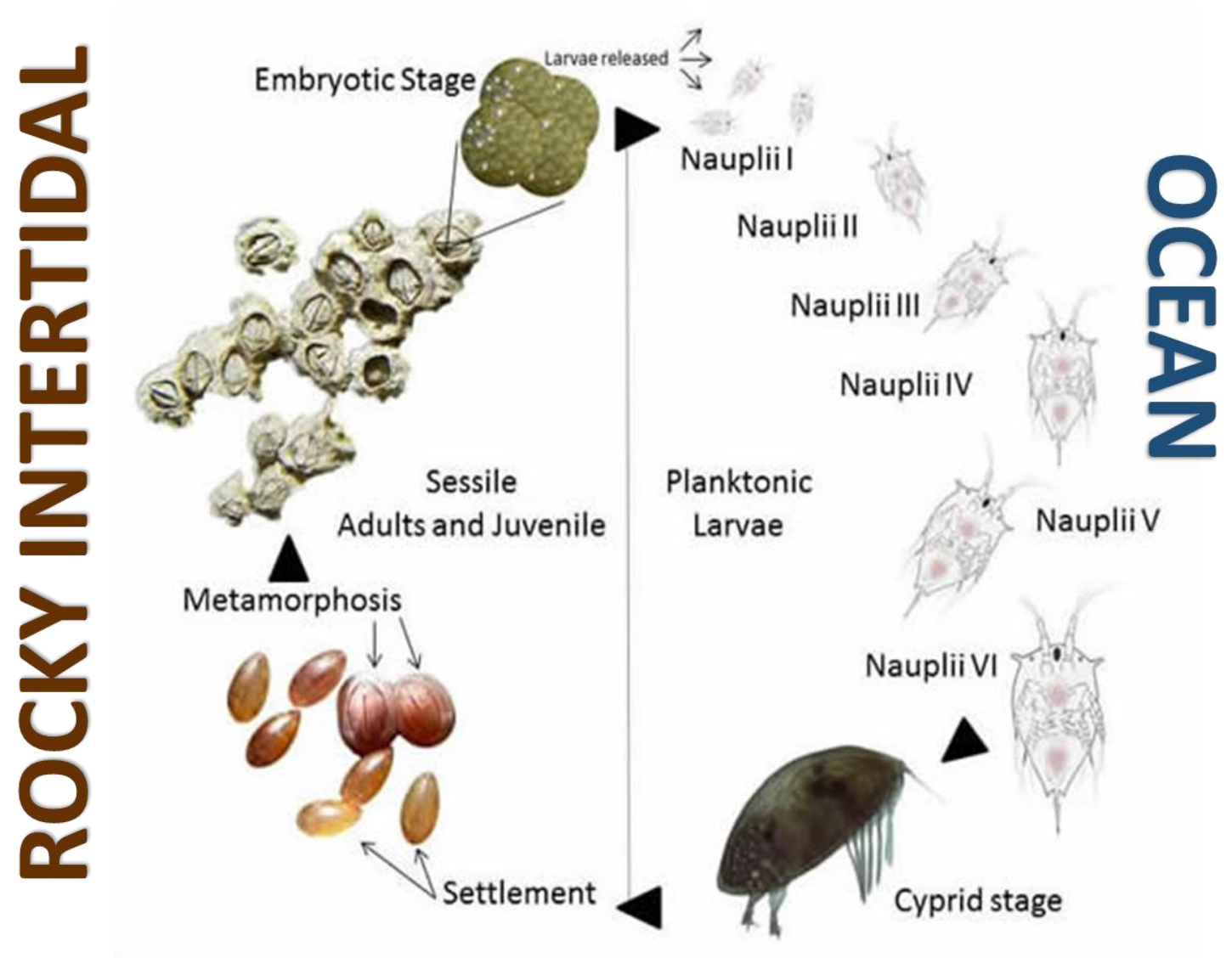


Figure 2. Processes influencing recruitment in bottom-dwelling species, as previously described in Pineda (2000). 


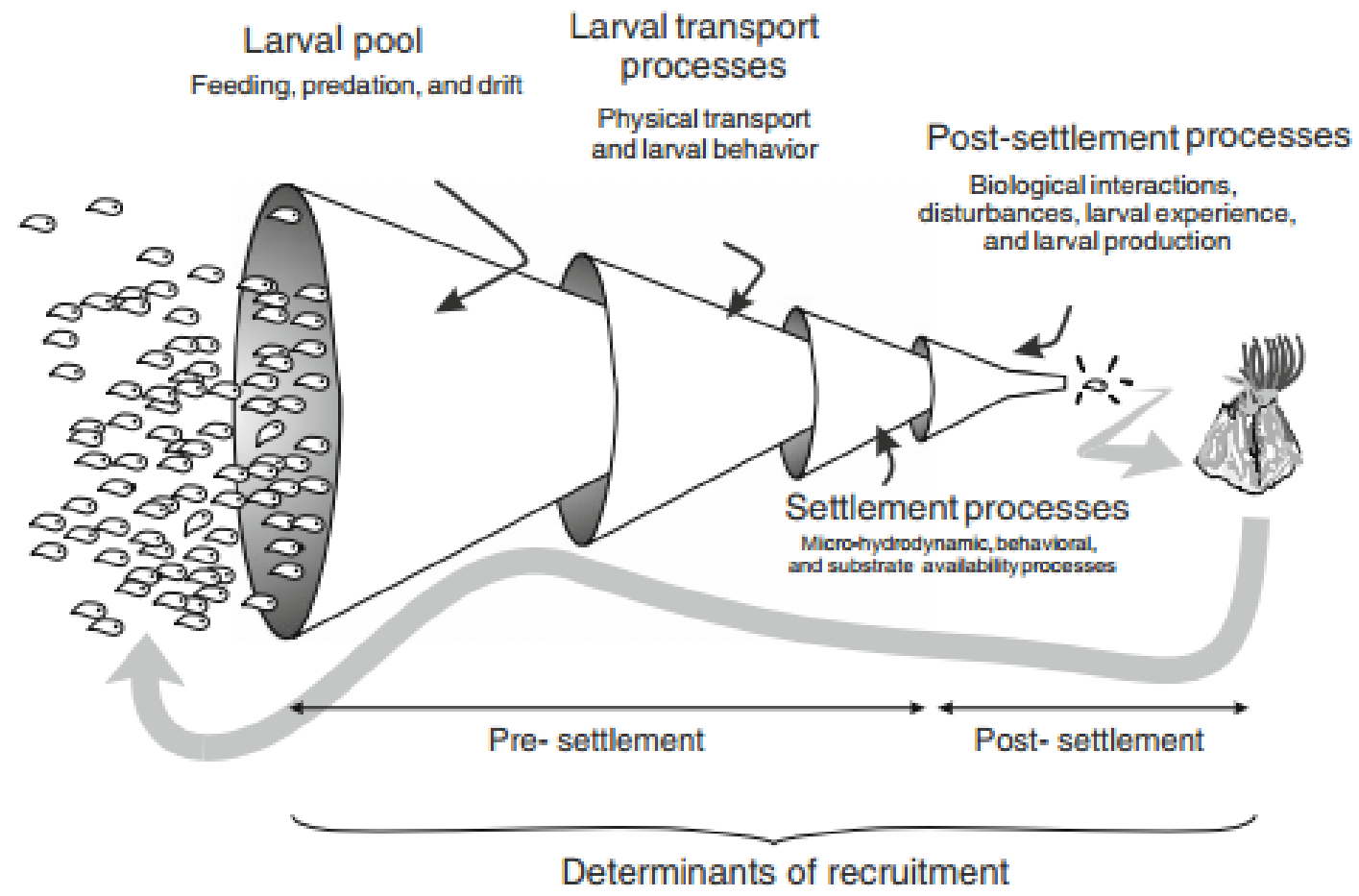




\title{
CHAPTER 2:
}

\section{Decoupling of larval supply and settlement and the potential habitat factors which influence settlement of Chthamalus fissus across space and time in the rocky intertidal of La Jolla, California, USA}

\begin{abstract}
The rocky intertidal contains a diversity of benthic, sessile invertebrates including the barnacle Chthamalus fissus, a primary space occupier. Barnacles serve as ideal model organisms for understanding the influence of pre- and postsettlement processes on the structure of intertidal populations. We examined the spatial and temporal dynamics of larval supply and settlement, their relationship, and how habitat characteristics (i.e. elevation as a proxy for immersion, proximity to the water's edge, and availability of free space) shaped settlement within the La Jolla, CA rocky intertidal. First, we deployed 6 larval traps to quantify the rate of daily larval supply, and 6 PVC settlement plates to quantify the rate of daily settlement in the Spring-Summer of 2014 and 2015. Secondly, we deployed 12 settlement plates from November 2014 to December 2015 and 14 plates from December 2015 to December 2016 to measure daily or weekly settlement, with monthly adult surveys conducted throughout this period. Settlement rate was higher in 2014 compared to 2015, with variability among settlement plate locations. Highs and lows in both larval supply and settlement corresponded across locations measured for a sample period. However, there was a limited relationship between larval supply and settlement. The decoupling between larval supply and settlement may result from the primary role the environment of the
\end{abstract}


nearshore plays in shaping each life history stage independent of one another in the La Jolla rocky intertidal. Settlement was minimally related to elevation as a proxy for immersion and not related to proximity to water, indicating these habitat characteristics play a less substantial role in shaping $C$. fissus settlement. However, a negative relationship between settlement rate and available free space provided support for the intensification effect, and free-space was driven by live barnacle and algae cover. This research suggests that, in addition to larval supply, local environmental processes or characteristics determine settlement of benthic invertebrate populations.

\section{INTRODUCTION}

The study of intertidal systems has contributed disproportionally to understanding community ecological processes including competition (Connell 1961 a, b), predation (Lubchenco \& Menge 1978, Menge 1983), disturbance (Dayton 1971), and the role of larval supply (Lewin 1986, Minchinton \& Scheibling 1991). Within these systems, benthic invertebrates such as barnacles serve as primary space occupiers, compete with other sessile organisms for space, are important prey, and contribute to community structure (Dayton 1971, Lubchenco \& Menge 1978, Chan et al. 2008, Zwerschke et al. 2013). Settlement and recruitment serve as fundamental processes in building the population dynamics and distributions of such species, acting as a pelagic-benthic transition between the larval and juvenile stages (Hatton 1938, Connell 1985, Gaines \& Roughgarden 1985, Carlon \& Olson 1993, Pineda et al. 2009). Settlement is the 
transition from a planktonic larva and includes the processes of habitat selection, permanent adhesion to a substrate, and metamorphosis to the benthic, juvenile stage (Pawlik 1992). Settlement rate (S) is usually defined in units of \# of larvae per unit area per time (e.g., \# larvae / $\mathrm{cm}^{2}$ day) (Pineda and Caswell 1997, Pineda et al. 2010).

The investigation of settlement dynamics is helpful to understand mechanisms of larval transport which supply populations with new individuals or recruits (Pineda 1994, Wing et al. 1995). Previous studies have suggested that processes influencing settlement dynamics include: a) adjusting settlement for immersion time to account for tidal fluctuations (Jarrett 1997, Shanks 2009), b) proximity to water (Gaines et al. 1985), c) free space for settlement (Gaines and Roughgarden 1985, Pineda 1994), d) larval behavior (Crisp and Meadows 1962, Pawlik 1992, Satumanatpan \& Keough 2001, Jenkins 2005), e) small-scale hydrodynamics (Crimaldi et al. 2002), and f) cannibalism (Maclsaac et al. 1991). Specifically, this research focuses on the dependence of settlement rate on the number of larvae near a settlement site, termed larval supply (Marshall et al. 2009, Pineda et al. 2010), and free space and the characteristics of the benthic habitat where larvae settle (Chabot \& Bourget 1988, Pineda \& Caswell 1997). Understanding pre-settlement processes that influence early barnacle life history is a complex subject in that larval abundance or supply near settlement sites is influenced by a multitude of factors affecting larval pool size, transport, and settling behavior (Connell 1985, Pineda 2000). Specifically, the relationship between larval supply and settlement is complex, as some studies have indicated a 
clear correlation, where larval supply predicts settlement (Minchinton and Schiebling 1991, Ross 2001, and Ma 2005), while other studies found no correlation between these two life history stages (Miron et al. 1995, Olivier et al. 2000, Rilov et al. 2008). The study of this transition is important to better understand how larval input modulates barnacle populations and community processes within the intertidal (Alexander and Roughgarden 1996, Hughes et al. 2000, Jonsson et al. 2004).

Most settlement studies addressing population dynamics and distribution emphasize the importance of larval supply (which determines the \# of larvae in calculating settlement rate). Few studies have addressed the importance of the benthic characteristics of the habitat area and the time interval when settlement is measured (which determines the area and time when calculating settlement rate), and substrate characteristics are often ignored (but see von der Meden et al. 2012). A series of recent studies have considered surf-zone width and characterized dissipative versus reflective beaches to examine the relationship between surf-zone hydrodynamics and settlement (e.g., Shanks et al. 2017, Morgan et al. 2018). While these studies have demonstrated higher settlement on dissipative compared to reflective beaches (Shanks et al. 2017, Morgan et al. 2018), they do not consider confounding effects; on dissipative beaches, where rock patches are usually surrounded by uninhabitable areas of sand, there should be less available substrate for settlement, which could act to intensify settlement (Morgan et al. 2018: Figure 8a, 8b from this article). When habitat availability is limiting, particularly for intertidal invertebrates, the settlement of individuals 
increases (e.g., Bertness \& Gaines 1993, Pineda 1994, Osman \& Whitlatch 1995a, Pineda \& Caswell 1997, von der Meden et al. 2012) and is termed the intensification effect (Pineda 1994, Pineda and Caswell 1997). Thus, it is important to consider the benthic characteristics of the substrate, and how they vary across a site when characterizing settlement patterns.

Research studies exploring spatial variability in settlement within intertidal shores (at few to $100 \mathrm{~m}$ scales) have considered three fundamental processes relating to the substrate. First, the result of spatial variation or patchiness in settlement is influenced by less free space (Gaines \& Roughgarden 1985, Minchinton \& Scheibling 1993, Pineda 1994, von der Meden et al. 2012, Scrosati \& Ellrich 2017). Secondly, the settlement dynamics of proximity to water indicate that sites closer to the water's edge receive more settlement (Gaines et al. 1985). The theory of proximity to water was supported by research that demonstrated the first suitable settlement sites encountered depleted larval supply to downstream sites, known as settlement shadow (Gaines et al. 1985). Finally, researchers assume the longer a settlement substrate is immersed in water, the more larval supply may be available for settlement (Minchinton and Scheibling 1991). Operationally, this is accomplished by standardizing settlement by immersion time (Minchinton \& Scheibling 1991, Jarrett 1997, Brown \& Swearingen 1998, Satumanatpan \& Keough 2001, Shanks 2009; but see Hatton 1938).

The extent to which these settlement processes and habitat characteristics influence a benthic population can help further inform the interaction of life 
history stages with one-another and the environment during the settlement of new individuals. Previous research suggests a discrepancy in the relationship between larval supply and settlement (Satumanatpan and Keough 2001, Jenkins 2005, Pineda et al. 2010). Investigating the dynamics of this disconnect may further help inform the role which the rocky intertidal habitat or environment (e.g., intensification, elevation as a proxy for immersion, and proximity to water) plays by influencing the early development of $C$. fissus and other benthic invertebrate populations (Minchinton and Scheibling 1991). This study addresses the following questions:

(a) What are the temporal (across sample periods) and spatial (few to 10's m) patterns in the variability of larval supply and settlement?

(b) Do locations that receive higher larval supply result in higher settlement?

(c) What are the temporal (weeks to years) and spatial (few to 10's m) patterns of settlement, as shaped by the benthic habitat? Are there consistent trends where some sites get more settlement than others, and are these trends persistent in time and space?

(d) Are these trends related to the intensification effect (do settlement sites surrounded by less suitable substrate for settlement receive more 
settlement), proximity to water or immersion time (do settlement sites closer to the edge of the water and/or immersed for a longer timeperiod receive more settlement)?

\section{MATERIALS AND METHODS}

\section{Study Site}

We examined the temporal-spatial dynamics of Chthamalus fissus larval supply, settlement, adult populations and habitat characteristics during a 2-year period in the rocky intertidal of Bird Rock, La Jolla, California, USA (Figure 1A). Bird Rock was selected for study because of the abundance of $C$. fissus adult barnacles and ample rocky intertidal habitat. This site is characterized by a gentlysloping intertidal shore, mainly consisting of cobbles and boulders with sizes ranging from $50-200 \mathrm{~cm}$ and a semidiurnal tide with a vertical range of -0.87 to $0.76 \mathrm{~m}$. The rocky intertidal extends along the coast for $\sim 575 \mathrm{~m}$ to the south before transitioning to a sandy beach. To the north of our site are $\sim 100 \mathrm{~m}$ of loose cobble beaches interspersed with sandy pocket beaches, where there is no habitat for barnacle settlement.

C. fissus was the most abundant barnacle species at our site (Hagerty et al. 2018). C. fissus larvae develop in the coastal ocean over a period of weeks, passing through six naupliar stages before developing into a cyprid stage (Brown \& Roughgarden 1985). Cyprids must return to the nearshore, find suitable habitat, settle, and undergo metamorphosis to the early juvenile stage to complete the initial phases of the barnacle life cycle (Pechenik et al. 1998). 


\section{Larval Supply and Settlement}

To compare larval supply and settlement, we established 8 locations within our study site where larval supply and settlement were concurrently measured (Figure 1B). Larval supply and settlement were measured daily at locations $3,7,8,9,12$, and 14 during June 16 to July 16, 2014 (referred to as '2014') and during April 24 to June 5, 2015 (referred to as '2015a'). However, study locations were altered during June 6 to August 2, 2015 (referred to as '2015b'), after larval traps (described below) at locations 3 and 8 were lost and had to be re-established at new locations: 1, 2, 7, 9, 12, and 14 (Figure 1B).

We deployed 6 cylindrical PVC larval traps modeled after those described in Chen et al. (2013) during the lowest low tide at locations approximately 0.66 to 12.6 m west from each settlement location to measure larval supply. Traps measured $18.2 \mathrm{~cm}$ high by $8.7 \mathrm{~cm}$ in diameter and the interior consisted of a segmented funnel that emptied into a $100 \mu \mathrm{m}$ mesh collection net (Appendix A). Rate of larval supply was estimated as the number of $C$. fissus and Balanus glandula cyprids collected per trap each day. The 2014 raw samples were sorted using a Meiji Techno RZ stereo microscope (3.75x-300x magnification). Barnacle cyprids by species and nauplii by stage (early vs late stage) were quantified. In spring-summer 2015, the traps collected substantial volumes of sand. Therefore, to facilitate further sorting, each sample was first stained with a rose Bengal and $100 \%$ ethanol solution. The sediment was then removed from the samples through a multi-step dilution. This process started by pouring a sample into a $1 \mathrm{~L}$ beaker, then water was added until the beaker was nearly full, and the sand particles were 
left to settle to the bottom. The water from the sample was decanted through a 100 $\mu \mathrm{m}$ mesh sieve and the above process was repeated until the water in the beaker was clear with no visible plankton retained on the mesh. The resulting sample was then reviewed in its entirety using the same method as the 2014 samples.

Daily settlement was measured by deploying settlement plates on rocks adjacent to larval traps during the lowest low tide (with the distances between described above). The tops of the larval traps and center line of the settlement plates were deployed at approximately the same elevation (average elevation of all traps and plates was $0.4 \mathrm{~m}$ relative to mean lower low water (MLLW), with a range of $0.3 \mathrm{~m}$ to $0.5 \mathrm{~m}$ relative to MLLW) (Appendix B). Settlement rate, the number of individuals per $\mathrm{cm}^{2}$ per day was measured using PVC settlement plates (as in Pineda 1994) with three grooves that provided $1.9 \mathrm{~cm}^{2}$ (each $\sim 95 \mathrm{~mm}$ long, $6 \mathrm{~mm}$ wide, $1 \mathrm{~mm}$ high) (Appendix C). Plates were processed using a Meiji Techno RZ stereo microscope (3.75x-300x magnification) to identify barnacle metamorphs (newly metamorphosed juveniles) to species.

Larval supply and settlement records did not meet the assumptions of parametric statistical tests, thus a Wilcoxon rank sum test with a continuity correction was used to determine if larval supply and settlement were different between 2014 and 2015. To investigate intra-site differences in larval supply and settlement, a Friedman's test with a multiple pairwise comparison using Nemenyi's procedure/two-tailed test was conducted to identify differences in each variable across locations within the site, by sample period. The relationship 
between $\log (\mathrm{x}+1)$ transformed larval supply and raw settlement was examined using a linear regression analysis in R-studio.

\section{Settlement and Habitat Characteristics}

To further compare settlement dynamics with respect to habitat characteristics, we measured the following variables at the 14 locations established within the site (Figure 1C). C. fissus settlement (\# of individuals per $\mathrm{cm}^{2} \mathrm{~d}$ ) was measured from April 2014 to December 2016 using the same PVC settlement plates described above. These plates were oriented along the contours of the rocks within the site and were collected and replaced at the lowest low tide of each day, then plates were processed as described above. Plates were collected at both daily and weekly timescales depending on the time of year and accessibility of the site due to the tides (Table 1); all settlement however, was reported as a daily rate. From April 24, 2014 to June 5, 2015, 12 plates were deployed along boulders within $\sim 50 \mathrm{~m}$ area along our study site (plates 3-14; Figure 1C). Then, to further test for the intensification effect, two additional plates (plates 1-2; Figure 1C) were also deployed for a total of 14 plates from June 6, 2015 to December 15, 2015 along the northernmost edge of the study site where suitable adult habitat was more limiting.

From daily and weekly settlement rates, monthly $C$. fissus settlement rate (\# of individuals per $\mathrm{cm}^{2} \mathrm{~d}$ ) was calculated by taking the average settlement rate for all plates deployed during each 30-day period leading up to the dates of the adult/habitat surveys (Table 1). To meet the criteria of calculating settlement for the 30 days prior to each survey, a minimum of 15 days of daily-collected 
settlement, three weeks of weekly-collected settlement, or a combination of both daily and weekly minimums were necessary. As such, May 2015, September 2015, and March 2016 were excluded from our analyses as settlement collections during these months did not meet the minimum requirements (Table 1). Because settlement from weekly sampling was lower than daily settlement, we used the regression describing the relationship between daily and weekly settlement previously established for our site (Pineda et al. in press). This regression was used to convert settlement data collected daily and averaged for the week, to weekly settlement values (weekly settlement, $\mathrm{y}=0.657 \mathrm{x}$, when daily settlement $(x) \leq 25.7$ individuals and $y=11.17+0.22 x$ when daily settlement $>25.7$ individuals) (Pineda et al. in press). The raw weekly values and/or daily-collected converted to-weekly values were then used to calculate monthly-averaged settlement (average \# settlers per $\mathrm{cm}^{2} \mathrm{~d}$ ) for the remaining 21 months of complete data for each location (Table 1).

To understand how the distribution and cover of adult $C$. fissus populations and habitat characteristics varied across the site, monthly surveys were conducted from December 2014 through December 2016 during new moon periods at the lowest low tide when the entire intertidal was accessible (Table 1). A 4 x $4 \mathrm{~cm}$ quadrat was haphazardly placed on top of the same rocks where settlement plates were deployed. Within the $16 \mathrm{~cm}^{2}$ area of the quadrat, percent cover of free space, live barnacles, dead barnacles, and algae were quantified by sampling 30 randomly selected (x, y) points within the quadrat (Appendix D). 
The elevation of plates 1 - 14 were measured in April 2017 using a Trimble R10 GNSS system which used a minimum of 5 satellites to obtain an average elevation (in meters) of the bolt at which each settlement plate was fastened to the boulder. These elevations were calculated by using the averages of the satellites to calculate the altitude of a specified position measuring how far away the position is from the satellites. Additionally, the position of each settlement plate relative to the water was determined in Google Earth Pro. From a satellite images of the research site, the longitude of plate 8 was used as a reference line, given this plate's closest proximity to the water (Google Earth 2016) (Figure 1). The distance between each location's longitude and the reference line was then calculated.

Given collinearity (variance inflation factor, VIF > 5) among habitat characteristics (percent free space, live barnacles, dead barnacles, and algae), we used separate linear regressions to examine the relationship between monthlyaveraged $C$. fissus settlement and each individual monthly-averaged habitat characteristic. To meet the assumptions of normality, we applied a logtransformation to the settlement record, and a hyperbolic arcsin-transformation to the percent cover of dead barnacles and algae. The percent free space and percent cover of live barnacles met assumptions of normality without need of transformation.

To identify which habitat characteristic best explained the variability in settlement, we assessed AIC and $\mathrm{R}^{2}$ values following Burnham \& Anderson (2002). A second-order corrected AIC ( AIC $_{c}$; used when $\left.\mathrm{n}<40\right)$ and Akaike 
weights were calculated to select the most parsimonious regression model describing the relationship between barnacle settlement and habitat characteristics (Burnham \& Anderson 2002). We also used this approach to assess the relationship between percent free space (the best-fit regression model explaining settlement variability), and the remaining habitat characteristics (percent cover of live barnacles, dead barnacles, and algae) to better understand the dynamics influencing percent free space within the rocky intertidal.

To examine consistency or intra-site variability in settlement, we calculated the average settlement per plate and average proportion of settlement per plate separately for the time periods corresponding to when 12 and 14 plates were deployed. Our data violated the assumptions of parametric tests despite transformation, thus a Friedman's test was used to determine if settlement differed among plates. Post-hoc pairwise comparisons using Nemenyi's multiple comparison tests were used to determine which plates were significantly different from one another. Pearson's product-moment correlations were also used to examine the relationship between the average proportion of settlement by plate in 2014 versus 2015, and the average proportion of settlement by plate with respect to plate elevation and proximity to water. 


\section{RESULTS}

\section{Larval Supply and Settlement}

Temporal patterns of larval supply and settlement

Larval supply and settlement were higher in 2014 than 2015, with little to no larval supply observed in 2015(Table 2). Additionally, the majority of cyprids and metamorphs collected were Chthamalus fissus (Table 2). There were significant differences between 2014 and 2015 for early-stage nauplii (Wilcoxon rank sum test, $\mathrm{W}=63851, \mathrm{p}<0.0001$ ), C. fissus cyprids (Wilcoxon rank sum test, $\mathrm{W}=31949, \mathrm{p}<0.0001$ ), Balanus glandula cyprids (Wilcoxon rank sum test, $\mathrm{W}=$ 22140, $\mathrm{p}=0.01$ ), other cyprid species (Wilcoxon rank sum test, $\mathrm{W}=22415, \mathrm{p}<$ 0.001), and $C$. fissus metamorphs (Wilcoxon rank sum test, $\mathrm{W}=319528, \mathrm{p}<$ 0.0001).

\section{Spatial patterns of larval supply and settlement}

Larval supply was temporally variable; however, peaks in larval supply were synchronous across traps, particularly during summer 2014 and 2015a (Figure 2A, 2B), but not in 2015b (Figure 2C). Larval supply was not significantly different by trap during all sample periods (Friedman's test, with all p-values $>0.05)($ Figure 2A, 2B, 2C). Settlement was also temporally variable (Figures 2D, 2E, 2F). There were significant differences in settlement across plates for 2014 (Friedman's test, $Q=58.69$, df $=5, \mathrm{p}<0.0001$ ), 2015a (Friedman's test, $\mathrm{Q}=80.05, \mathrm{df}=5, \mathrm{p}<0.0001$ ), and 2015b (Friedman's test, $\mathrm{Q}=$ 75.74, df = 5, p < 0.0001; Figure 2D, 2E, 2F). Thus, settlement was ranked by location, and fell into three groups based on similarity of ranks in 2014 (Table 3), 
four groups in 2015a (Table 4), and two groups in 2015b (Table 5). In all three periods, settlement was highest at locations 7 and 9 and lowest at locations 12 and 14 (Tables 3, 4, and 5).

\section{Relationship between larval supply and settlement}

The relationship between larval supply and settlement was highly variable across each sample period (2014, 2015a, and 2015b) and 8 locations (Figure 3A, 3B, 3C). In 2014, there was a positive relationship between average larval supply and settlement by location, however, this relationship was non-significant (Linear regression, $\mathrm{R}^{2}=0.46, \mathrm{p}=0.14$; Figure $3 \mathrm{~A}$ ). When examined by location, larval supply was significantly related with settlement only in 2014, when larval supply was high, at location $4\left(R^{2}=0.31, p=0.001\right)$, location $7\left(R^{2}=0.24, p=0.005\right)$, and location $8\left(R^{2}=0.14, p=0.03\right)$. In 2015a, there was a non-significant relationship (Linear regression, $\mathrm{R}^{2}=0.18, \mathrm{p}=0.40$; Figure 3B), while in $2015 \mathrm{~b}$ there was a marginally significant negative relationship (Linear regression, $\mathrm{R}^{2}=$ $0.69, p=0.03$; Figure $3 \mathrm{C}$ ) between average larval supply and settlement across locations. Based on these results we further investigated the relationship between settlement and the habitat characteristics.

\section{Settlement and Habitat Characteristics}

Relationship between settlement and tidal related factors

There was a weak non-significant positive correlation between average proportional settlement and elevation, a proxy for immersion time $(\mathrm{R}=0.56, \mathrm{p}=$ 0.06; Figure 4A), and no correlation between average proportional settlement and proximity to water $(R=-0.23, p=0.47$; Figure $4 B)$. 


\section{Temporal patterns of settlement and adults/habitat cover}

Monthly-averaged settlement rate varied with time. Settlement was low during the winter to early spring months (December through March), with slight increases during summer and fall 2015. The highest settlement occurred in July to October 2016 (Figure 5A). Monthly-averaged percent free space was high during the winter to late spring months (December through May), decreased during the summer through September, before increasing again in the fall through the winter (Figure 5B). Monthly-averaged percent cover of live barnacles was highest during the summer months (June through August), but sharply decreased in September of both 2015 and 2016 (Figure 5C). The monthly-averaged percent cover of dead barnacles was low $(<10 \%)$ during December 2014 to November 2016; but increased from September to November in both 2015 and 2016, corresponding to the periods of low percent cover of live barnacles (Figure 5C, 5D). Monthlyaveraged percent cover of algae varied more than percent cover of dead barnacles; but was greatest in September of 2015 and 2016 (Figure 5E).

\section{Relationship between settlement and free space}

Of the habitat factors examined, variability in monthly-averaged C. fissus settlement was best explained by monthly-averaged percent free space. This model had the lowest $\mathrm{AIC}_{\mathfrak{c}}$, and a $92 \%$ probability of being the correct model of all candidate models; given the evidence ratios $>10$, models with percent cover of live barnacles, percent cover of dead barnacles, and percent cover of algae were not deemed suitable (Table 6). C. fissus monthly-averaged settlement was significantly negatively correlated with monthly-averaged percent free space for 
all settlement plates (range of $\mathrm{R}^{2}$ values from 0.05 to $0.47, \mathrm{p}<0.05$ ) except at locations 2, 4, 5, 10, and 11 (Figure 6), and when monthly settlement (logtransformed) and percent free space were averaged over all plates $\left(R^{2}=0.55, p\right.$ $<<0.001 ;$ Figure 7).

Relationship between free space and live barnacle and algae cover

Percent free space was not related to percent cover of live barnacles $\left(\mathrm{R}^{2}=\right.$ $0.05, p=0.31 ;$ Figure $8 A)$ or percent cover of dead barnacles $\left(R^{2}=0.02, p=0.46\right.$; Figure 8B), but there was a negative relationship with percent cover of algae $\left(\mathrm{R}^{2}=\right.$ $0.56, \mathrm{p}<<0.001$; Figure 8C). Variability in monthly-averaged percent free space was best explained by the model that included percent cover of live barnacles and algae (62\% probability of being the best model; Table 7). While the model including percent cover of live barnacles, dead barnacles, and algae had a $37 \%$ probability of being the best model, the evidence ratios $<2.0$ for both these models provided insufficient evidence to suggest that one model was better than the other in explaining variability in percent free space. To further refine which explanatory variables best explained the variability in percent free space, we ranked the relative importance of possible explanatory variables. Percent cover of algae (100\%) and percent cover of live barnacles $(99.95 \%)$ had greater relative importance in explaining the variability in percent free space than percent cover of dead barnacles (37.04\%; Table 8). Thus, we accepted the model including percent cover of live barnacles and algae as the best model explaining the variability in percent free space $\left(R^{2}=0.81, p<0.001\right)$. 
Intra-site spatial patterns of settlement

C. fissus settlement varied within our site in the rocky intertidal. When settlement (average \# per $\mathrm{cm}^{2} \mathrm{~d}$ or proportion of settlers) was compared by plate for the time period that 12 plates were deployed, plates 3, 7, and 9 had the highest settlement, and plates 5 and 6, had the lowest settlement (Figure 9A). For the period that all 14 plates were deployed, plates 1 through 3,7 , and 9 had the highest settlement and plates 4 through 6 had the lowest settlement (Figure 9B). Further, there was a strong positive correlation between the proportion of $C$. fissus settlement on plates deployed in 2014 versus the proportion of settlement on plates deployed in $2015(\mathrm{R}=0.77, \mathrm{p}=0.002$; Figure 9C). There was a significant difference in settlement among plates at our site for both the 12-plate deployment period (Friedman's test: $\chi 2=19.67, \mathrm{p}<<0.001$; Table 9) and 14-plate deployment period (Friedman's test: $\chi 2=22.36, \mathrm{p}<<0.001$; Table 10). Multiple pairwise comparisons confirmed that plate 9 was ranked with the highest settlement and plate 6 was ranked with the lowest settlement, during both the 12plate (Figure 10A) and 14-plate (Figure 10B) deployment periods. Settlement was also high at plate 3 (nearest the northern boundary of the settlement plate locations) during the 12-plate deployment period (Figure 10A, 10B). However, plate 2 was ranked with equally-high settlement as plate 3 during the 14-plate deployment period (Figure 10A, 10B).

\section{DISCUSSION}

Settlement processes and environmental factors influence early life history of benthic species, playing an important role in shaping populations (Fraschetti et 
al. 2002). Many studies have investigated the influence of settlement processes and environmental factors on barnacle species' populations within the rocky intertidal (Farrell et al. 1991, Bertness et al. 1992, Olivier et al. 2000, Jenkins 2005, Pineda et al. 2010, Rivera et al. 2013). Specifically, some studies addressed the dependence of settlement rate on larval supply (Miron et al. 1995, Ross 2001, Pineda et al. 2010); however, processes influencing settlement habitat can also influence settlement rate (Gaines and Roughgarden 1985, Lewin 1986, Pineda 1994, Eckman 1996, Hoffmann et al. 2012). We examined the relationship between larval supply and settlement, and the influence of habitat elevation, proximity to water, and percent of available free space on settlement.

For both larval supply and settlement, $C$. fissus was the dominant species within our site in the spring-summer and therefore contributed most heavily to the adult populations, as previously observed in nearshore waters off La Jolla (Tapia and Pineda 2007, Hagerty et al. 2018). When comparing larval supply and settlement in the summer of 2014 relative to those measured in the summer of 2015, the rates of larval supply and settlement were higher in 2014 for each of the major categories of organisms collected: early stage nauplii, Chthamalus fissus, Balanus glandula, other species cyprids, and Chthamalus fissus metamorphs. The difference in the magnitude of values for 2014 versus 2015 may have been due to conditions being more conducive for larval transport, providing a larger availability of larvae within the water column in 2014. Other studies observed similar decreases in larval counts from 2014 to 2015 within the southern California coastal region (Basilio et al. 2017, Hagerty et al. 2018). Larval 
decreases may have been due to the prominence of the warm blob event in San Diego towards the end of 2014 (Basilio et al. 2017, Pineda et al. in press), or El Niño in 2015 (McClatchie et al. 2016). Changes in sea surface temperature associated with El Niño can influence larval transport mechanisms (Tegner and Dayton 1991, Barth et al. 2007, Lot-Yat et al. 2011). Decreases in larval abundances may also be due to reduced levels of chlorophyll $a$ (Paulay et al. 1985, Lo-Yat et al. 2011) or changes in local, small-scale hydrodynamics (Bertness et al. 1996, Jacinto and Cruz 2008) both resulting from El Niño conditions in 2015.

To understand the causes of the decreases in larval abundances it is important to consider the basal larval transport processes. Previous studies observed higher recruitment with discrete periods of upwelling in a variety of locations (Shanks et al. 2000, Iles et al. 2011, Rivera et al. 2013). In the intermittent time between upwelling periods (relaxation of upwelling-favorable winds) larvae might converge at a front (Roughgarden et al. 1991) which might be transported to shore through tidally generated internal waves (Shanks et al. 2009), that form at density gradients (Hagerty et al. 2018). Thus, a breakdown in larval transport may be due to El Niño's inhibition or delay of relaxation periods which may lead to decreases in primary productivity and settlement of benthic invertebrates (Lundquist et al. 2000, Barth et al. 2007). Therefore, the warming SST from 2014 to 2015 (Zaba and Rudnick 2016), leading into the El Niño period may have altered larval delivery to the shore resulting in a reduction in the larval pool (\# of individuals available for settlement and subsequent recruitment). 
Across the two years of observations (December of 2014 to December of 2016), settlement of C. fissus varied seasonally, with similar patterns to those documented in previous studies of higher settlement rates observed in the spring to summer than the fall to winter period (Pineda 1994, Tapía and Navarrete 2010). Settlement also decreased in the fall to winter months possibly due to seasonal or annual variation in the physical mechanisms that altered the delivery of larvae to shore decreasing the larval pool available for settlement (Broitman et al. 2005, Pineda et al. 2007, Menge et al. 2009, Menge et al. 2011, Hagerty et al. 2018).

Temporal fluctuations in larval supply corresponded across all traps; however, there were significant differences in settlement rate across plates per period within our site. Furthermore, the peaks in larval supply did not necessarily correspond with timing of peaks in settlement. The decoupling between larval supply and settlement time series could possibly indicate that the larval traps do no accurately represent the larval supply to our site. However, we used a known, tested trap design that previously collected barnacle cyprids in the rocky intertidal (Chen et al. 2013). Additionally, all traps exhibited similar patterns of larval supply, suggesting that they functioned similarly across our study site. Although we observed cases where larval supply was low, and settlement was high, these observations may potentially reflect a lag between the time larvae first arrive in the intertidal (larval supply) and when they find suitable habitat and settle (Swanson et al. 2007). However, this lag may also occur if larvae have an extended or variable competency period within the intertidal (Mccormik et al. 2012, Rahman et al. 2014). 
With low larval abundances observed in 2015 and our limitations in conducting a more robust time series analyses of larval supply and settlement, our assertion that there was a lack of relationship between larval supply and settlement based on the 2014 data. Variability in the relationship between settlement and larval supply was previously observed with some studies showing a negative correlation (Miron et al. 1995), positive correlation (Minchinton and Scheibling 1991, Ma 2005), negative or positive correlation dependent on larval delivery (Olivier et al. 2000), or no correlation (Satumanatpan and Keough 2001, Rilov et al. 2008) between larval supply and settlement. Given this variability and our own observations, we cannot definitively state that settlement may be predicted from larval supply. This decoupling between larval supply and settlement may be due to the environmental conditions experienced at settlement, including immersion time, proximity to water, and space available for settlement within the Bird Rock rocky intertidal.

Previous studies have utilized immersion time to standardize settlement rate (Jarrett 1997, Shanks 2009) and proximity to water's edge was suggested to influence settlement rate to a locality (Gaines et al. 1985). Although at some point elevation will matter (i.e. when settlement substrates are outside the water with respect to tidal changes), within the mid to high intertidal (i.e. where our settlement plates were distributed), we found minimal evidence that elevation was related to $C$. fissus settlement. Therefore, researchers should not assume immersion time (with respect to tidal cycle) linearly determines settlement rate, given the varying degree of correlation observed between these two variables 
(Hatton 1938, Shanks 1986, Hills et al. 1998, Pineda 2000, Cruz et al. 2005). Similarly, we found that proximity from the edge of the water did not have a direct influence on settlement. In the past, proximity to water was used to invoke a settlement shadow, that is, the first plates/rocks encountered by a parcel of water as the tide is rising might deplete larval supply to downstream plates (Gaines et al. 1985). However, based on the non-relationship between settlement and proximity to water, there was no evidence of a settlement shadow at our site.

We observed that with less free space there was higher settlement. This observation is opposite of the patterns observed by Gaines and Roughgarden (1985) who found more settlement with more free space and Jeffrey (2000) who found that substratum had no effect on barnacle settlement where adult density was low. The negative relationship between free space and settlement was observed at all settlement plates, indicative of a settlement intensification effect across our site (Bertness et al. 1992, Pineda 1994, Osman \& Whitlatch 1995a, b, Pineda \& Caswell 1997, Berntsson et al. 2004, Rilov et al. 2008, von der Meden et al. 2012). Similarly, Pineda (1994) observed an increase in Chthamalus spp. settlement when the amount of unsuitable surrounding habitat increased, minimizing the amount of free space available.

Given the diversity of habitat cover in the rocky intertidal, free space is a function of percent cover of adult barnacles and algae. We observed a negative relationship between settlement and live barnacles resulting in less settlement with high live barnacle cover. This relationship is opposite of what would be expected for typical gregarious larval barnacle settlement in response to recent 
recruits, juveniles, or adults of conspecifics (Crisp \& Knight-Jones 1953, Crisp \& Meadows 1962, Chabot and Bourget 1988, Jeffery 2000, Matsumura \& Qian 2014). Gregarious settlement can generally be facilitated by the ability of larvae to detect chemical cues and selectively settle based on the presence or absence of conspecific adults (Pawlik 1992, Scrosati and Ellrich 2017). The observed negative relationship between barnacle adults and settlers may be influenced by post-settlement mortality which results in a smaller adult barnacle population than the initial newly-settled population (Minchinton \& Scheibling 1993). Settlement was positively related to algal cover. Overall, algal cover remained consistently low around $20 \%$, only peaking in late summer through the fall. Previous research demonstrated the influence of algal cover (Jernakoff \& Fairweather 1985) and its associated chemical cues (Walters et al. 1996) on limiting the suitable space available for benthic invertebrate settlement. Therefore, algal cover may have driven the intensification effect (Pineda 1994) where less space available due to algal coverage enhanced settlement. This study highlighted the influence of additional space occupiers (e.g., adult barnacles and algae) on the space available for settlement of Chthamalus fissus similar to previous studies such as Luckens (1975) and Beermann et al. (2013).

Within our site, there was a consistency in the ranking of settlement rate among plates from the time period using 12 plates to all 14 plates. For the 12plate period, the plates with the lowest settlement rankings (plates 5 and 6) were near locations where habitat was less limiting and the locations where settlement rankings were highest (plates 3, 7, and 9) were where habitat was more limited. 
Based on the high settlement at plate 3 and the knowledge that moving from north to south habitat was less limiting with increasing cobbles available, we added plates 1 and 2 to the north end of our site during the 14-plate period. We observed high settlement at plates 1 and 2 in addition to plates 3, 7, and 9. These increases in settlement with less free space at locations 1,2, and 3 were further evidence of the intensification effect, similar to Pineda and Caswell (1997). Locations 7 and 9 however, had consistently high settlement when compared to both larval supply and habitat characteristics, despite not being in locations where available adult habitat was limiting. This suggests that other factors in addition to the intensification effect may have influenced settlement dynamics at some locations within our site. These factors may include the microhydrodynamic conditions around settlement substrate and larval behavior during settlement. Previous studies have demonstrated that the ability of larvae to settle is dependent on the scaling of small-scale hydrodynamics and how these may or may impede the detection of conspecifics (Wright and Boxshall 1999, Crimaldi et al. 2002). Thus, within the Bird Rock rocky intertidal, settlement at 1-month temporal time scales may be influenced by small-scale benthic processes such as habitat cover, small scale hydrodynamics, and larval behavior at settlement. To extend our understanding of the influence of small-scale processes in shaping settlement dynamics at our site we need to quantify the temporal duration of competency for C. fissus and characterize the location of arrival of larvae within our rocky intertidal site. To investigate these two-components we must consider the role of hydrodynamics (Pineda 1991, Bertness et al. 1996, Jacinto and Cruz 2008, Rilov 
et al. 2008) in influencing the early larval behavior (Crisp 1955, Haury et al. 1982, Miron et al. 1996, Wright and Boxshall 1999, Crimaldi et al. 2002, Kent et al. 2003) of barnacles which ultimately leads to settlement (Hawkins and Hartnoll 1982).

\section{Conclusions}

Within our site, there was evidence of decoupling between larval supply and settlement. One possible explanation for this decoupling is that habitat characteristics or availability of free space influenced C. fissus settlement. Availability of free space was determined by live barnacle and algal cover. However, it is possible that additional microhydrodynamic features, such as micro-eddies (Crimaldi et al. 2002, Koehl 2007) and aspects of larval behavior (Crisp 1974, Miron et al. 1996, and Kent et al. 2003) also influence barnacle larval supply and settlement. Therefore, invoking just larval supply or larval transport processes to explain settlement rate is misleading; variability in substrate availability can further explain settlement rate dynamics. Investigating the influence of habitat on settlement patterns within coastal ecosystems is important to understand the settlement processes shaping benthic invertebrate populations. Some studies have acknowledged settlement intensification on reflective beaches; but have mainly focused on the influence of surf-zone hydrodynamics on settlement at reflective versus dissipative beaches (Shanks et al. 2017, Morgan et al. 2018). The role of intensification and other habitat or environmental factors must be considered to fully understand the post-settlement processes and environmental factors that help shape rocky intertidal communities. 
CHAPTER 2 TABLES AND FIGURES 
Table 1. Chthamalus fissus sampling dates for settlement $(\mathrm{D}=$ daily, $\mathrm{W}=$ weekly, or both, depending on the accessibility of the site) and surveys of adult populations and habitat ( $\mathrm{M}=$ monthly) from April 2014 to December 2016. 


\begin{tabular}{cccc} 
Month & $\mathbf{2 0 1 4}$ & $\mathbf{2 0 1 5}$ & $\mathbf{2 0 1 6}$ \\
\hline January & & $\mathrm{D}, \mathrm{W}, \mathrm{M}$ & $\mathrm{W}, \mathrm{M}$ \\
February & & $\mathrm{W}, \mathrm{M}$ & $\mathrm{W}, \mathrm{M}$ \\
March & & $\mathrm{W}, \mathrm{M}$ & $\mathrm{W}, \mathrm{M}$ \\
April & $\mathrm{D}$ & $\mathrm{D}, \mathrm{W}, \mathrm{M}$ & $\mathrm{D}, \mathrm{W}, \mathrm{M}$ \\
May & $\mathrm{D}$ & $\mathrm{D}, \mathrm{M}$ & $\mathrm{D}, \mathrm{M}$ \\
June & $\mathrm{D}$ & $\mathrm{D}, \mathrm{M}$ & $\mathrm{D}, \mathrm{M}$ \\
July & $\mathrm{D}$ & $\mathrm{D}, \mathrm{M}$ & $\mathrm{D}, \mathrm{M}$ \\
August & & $\mathrm{D}, \mathrm{W}, \mathrm{M}$ & $\mathrm{D}, \mathrm{M}$ \\
September & & $\mathrm{D}, \mathrm{W}, \mathrm{M}$ & $\mathrm{D}, \mathrm{M}$ \\
October & $\mathrm{D}$ & $\mathrm{D}, \mathrm{M}$ & $\mathrm{D}, \mathrm{M}$ \\
November & $\mathrm{D}$ & $\mathrm{D}, \mathrm{M}$ & $\mathrm{D}, \mathrm{M}$ \\
December & $\mathrm{D}, \mathrm{M}$ & $\mathrm{D}, \mathrm{W}, \mathrm{M}$ & $\mathrm{D}, \mathrm{M}$
\end{tabular}


Table 2. Averages ( $\pm \mathrm{SE}$ ) and proportions of barnacle larvae (out of each subcategory nauplii, cyprids, and settlement species) collected in larval traps (measure of larval supply) and on settlement plates (measure of settlement) during summer 2014 and summer 2015. 


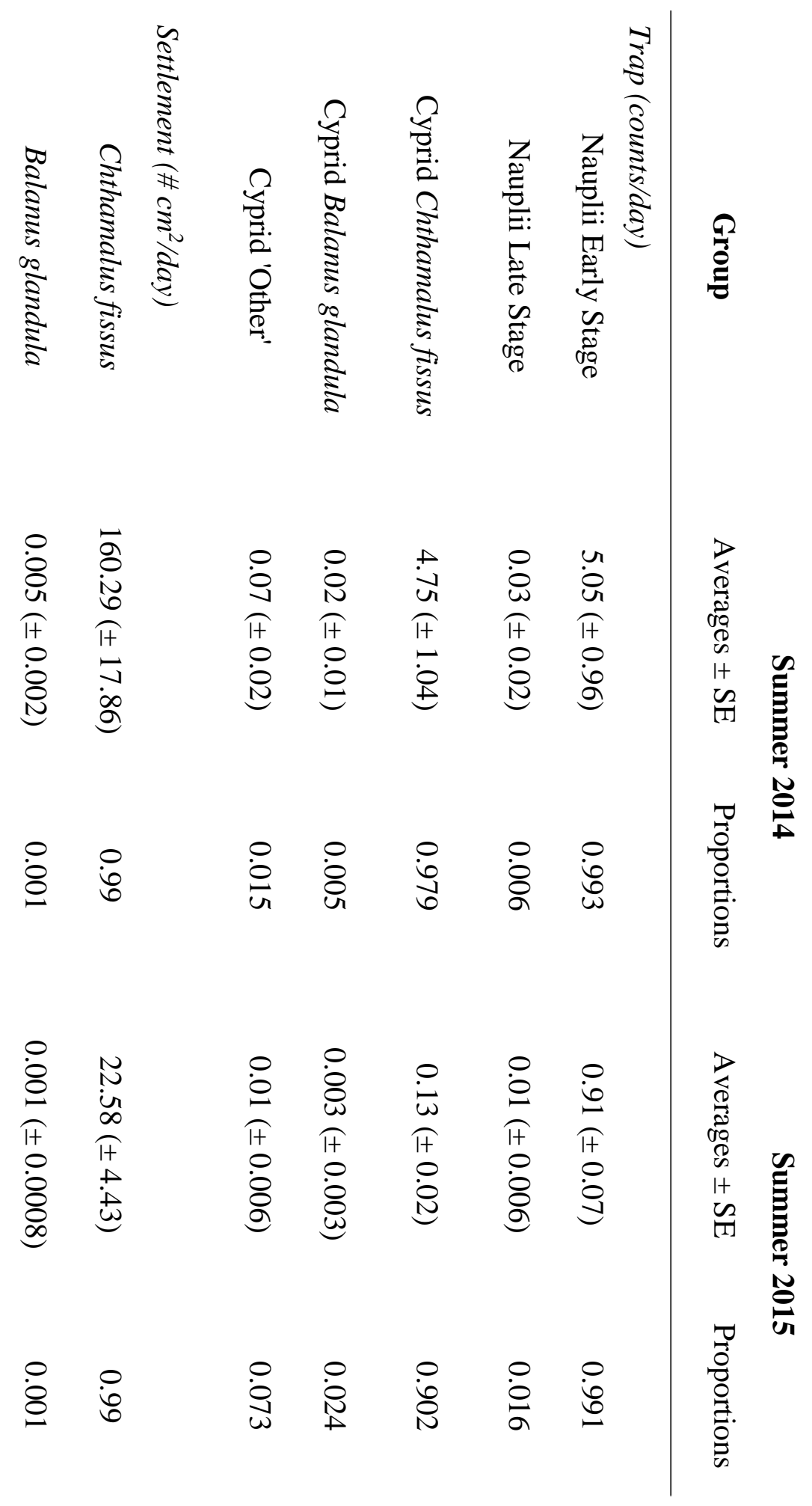


Table 3. Average rank for settlement, by location for 2014 (June $16^{\text {th }}-$ July $16^{\text {th }}$, 2014) using Nemenyi's procedure / two-tailed test. The locations with similar ranks are grouped as A-C. 


\begin{tabular}{cc|ccc}
\hline Location & Average of Ranks & \multicolumn{3}{|c}{ Groups } \\
\hline 8 & 2.145 & $\mathrm{~A}$ & & \\
14 & 2.371 & $\mathrm{~A}$ & & \\
12 & 3.016 & $\mathrm{~A}$ & $\mathrm{~B}$ & \\
3 & 4.145 & & $\mathrm{~B}$ & $\mathrm{C}$ \\
7 & 4.387 & & & $\mathrm{C}$ \\
9 & 4.935 & & & $\mathrm{C}$
\end{tabular}


Table 4. Average rank for settlement, by location for 2015a (April $24^{\text {th }}$ - June $5^{\text {th }}$, 2015) using Nemenyi's procedure / two-tailed test. The locations with similar ranks are grouped as A-D. 


\begin{tabular}{cc|cccc}
\hline Location & Average of Ranks & \multicolumn{5}{c}{ Groups } \\
\hline 12 & 1.791 & A & & & \\
8 & 2.744 & A & B & & \\
14 & 3.302 & & B & C & \\
3 & 3.907 & & & C & D \\
9 & 4.512 & & & & D \\
7 & 4.744 & & & & D
\end{tabular}


Table 5. Average rank for settlement, by location for 2015b (June $6^{\text {th }}$ - August $2^{\text {nd }}, 2015$ ) using Nemenyi's procedure / two-tailed test. The locations with similar ranks are grouped as A and B. 


\begin{tabular}{cc|cc}
\hline Location & Average of ranks & \multicolumn{2}{|c}{ Groups } \\
\hline 12 & 2.448 & $\mathrm{~A}$ & \\
14 & 2.612 & $\mathrm{~A}$ & \\
1 & 2.983 & $\mathrm{~A}$ & \\
2 & 4.069 & & $\mathrm{~B}$ \\
7 & 4.216 & & $\mathrm{~B}$ \\
9 & 4.672 & & $\mathrm{~B}$
\end{tabular}


Table 6. Results of model selection using information theoretic criteria to quantify the relationship between monthly-averaged settlement of Chthamalus fissus and percent cover of live barnacles, dead barnacles, free space, and algae, $\mathrm{n}$ $=21$ months.

Table values were calculated from regression analysis on models that included monthly-averaged log-transformed settlement of $C$. fissus as the response variable, and monthly-averaged percent cover of live barnacles and free space and hyperbolic arcsin-transformed percent cover of dead barnacles and algae as explanatory variables.

$K$ is number of explanatory variables included in model $+1, A I C_{\mathrm{c}}$ is second-order corrected AIC for sample size $<40$.

$\triangle A I C_{\mathrm{c}}$ is the difference between $\mathrm{AIC}_{\mathrm{c}}$ of each model and the model with lowest $\mathrm{AIC}_{\mathrm{c}}$. Weights are Akaike weight of evidence (probability) that model is best approximating model in a given set of candidate models. Evidence Ratio is evidence supporting best approximating model.

*Model with lowest $\mathrm{AIC}_{\mathrm{c}}$ against which all other models are compared. 


\begin{tabular}{cccccc}
$\begin{array}{c}\text { Explanatory } \\
\text { Variable } \\
(\% \text { cover })\end{array}$ & $\mathbf{K}$ & $\mathbf{A I C}_{\mathbf{c}}$ & $\boldsymbol{\Delta A \mathbf { I C } _ { \mathbf { c } }}$ & Weights & Evidence Ratio \\
\hline Live Barnacles & 2 & 12.034 & 16.4445 & 0.0003 & 3722.9591 \\
Dead Barnacles & 2 & 5.057 & 9.4676 & 0.0081 & 113.7259 \\
Free Space & 2 & -4.410 & 0 & 0.9242 & $1 *$ \\
Algae & 2 & 0.826 & 5.2365 & 0.0674 & 13.7115
\end{tabular}


Table 7. Results of model selection using information theoretic criteria to quantify the relationship between monthly-averaged percent free space and percent cover of live barnacles, dead barnacles, and algae, $\mathrm{n}=21$ months.

Table values were calculated from regression analysis on models that included monthly-averaged percent free space as the response variable, and monthlyaveraged percent cover of live barnacles and hyperbolic arcsin-transformed percent cover of dead barnacles and algae as explanatory variables.

$K$ is number of explanatory variables included in model $+1, A I C_{\mathrm{c}}$ is second-order corrected AIC for sample size $<40$.

$\triangle A I C_{\mathrm{c}}$ is the difference between $\mathrm{AIC}_{\mathrm{c}}$ of each model and the model with lowest $\mathrm{AIC}_{\mathrm{c} .}$ Weights are Akaike weight of evidence (probability) that model is best approximating model in a given set of candidate models. Evidence Ratio is evidence supporting best approximating model.

*Model with lowest $\mathrm{AIC}_{\mathrm{c}}$ against which all other models are compared. 


\begin{tabular}{cccccc}
$\begin{array}{c}\text { Explanatory Variable } \\
(\% \text { cover})\end{array}$ & $\mathbf{K}$ & $\mathbf{A I C}_{\mathbf{c}}$ & $\boldsymbol{\Delta A I C}_{\mathbf{c}}$ & Weights & Evidence Ratio \\
\hline Live Barnacles & 2 & 125.495 & 31.5426 & $8.90 \mathrm{E}-08$ & 7069670.020 \\
Dead Barnacles & 2 & 126.034 & 32.0820 & $6.79 \mathrm{E}-08$ & 9258099.934 \\
Algae & 2 & 109.081 & 15.1291 & 0.000361 & 1928.643 \\
Live Barnacles, Dead Barnacles & 3 & 124.492 & 30.5394 & $1.46 \mathrm{E}-07$ & 4280974.374 \\
Live Barnacles, Algae & 3 & 93.952 & 0 & 0.629241 & $1 *$ \\
Dead Barnacles, Algae & 3 & 110.434 & 16.4815 & 0.000163 & 3792.358 \\
Live Barnacles, Dead Barnacles, Algae & 4 & 95.013 & 1.0606 & 0.370267 & $1.699 *$
\end{tabular}


Table 8. Ranked relative importance of factors explaining the variability in percent free space from the Akaike weights in Table $7, \mathrm{n}=21$ months. 


\begin{tabular}{ccc} 
Explanatory Variable & Relative importance & \% importance \\
\hline Algae & 1.0000 & 100.00 \\
Live Barnacles & 0.9995 & 99.95 \\
Dead Barnacles & 0.3704 & 37.04
\end{tabular}


Table 9. Significance values (values with a $\mathrm{p}<0.05$ are in bold) comparing $C$. fissus settlement across plate pairs for plates 3-14 (April 24th, 2014 to June 5th, 2015, $\mathrm{n}=217$ days per plate) using a multiple pairwise comparison Nemenyi's two-tailed test. 


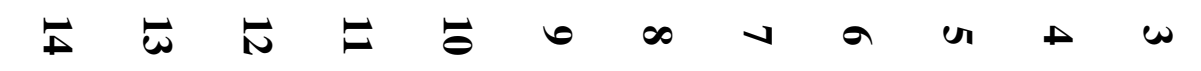

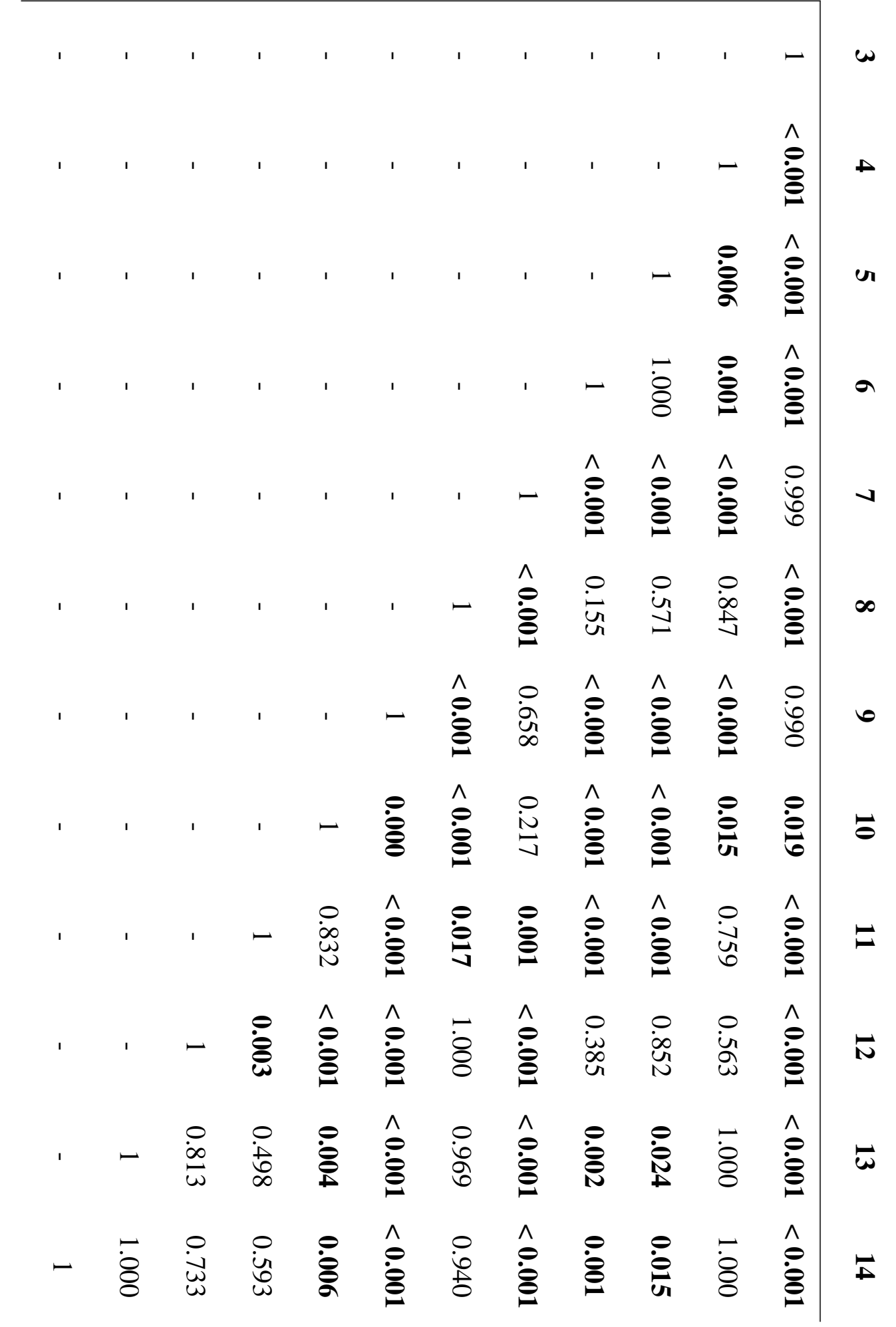


Table 10. The significance values (values with a $\mathrm{p}<0.05$ are in bold) comparing C. fissus settlement across plate pairs for plates 1-14 (June $6^{\text {th }}, 2015$ to December $15^{\text {th }}, 2015, \mathrm{n}=156$ days per plate) using a multiple pairwise comparison Nemenyi's two-tailed test 


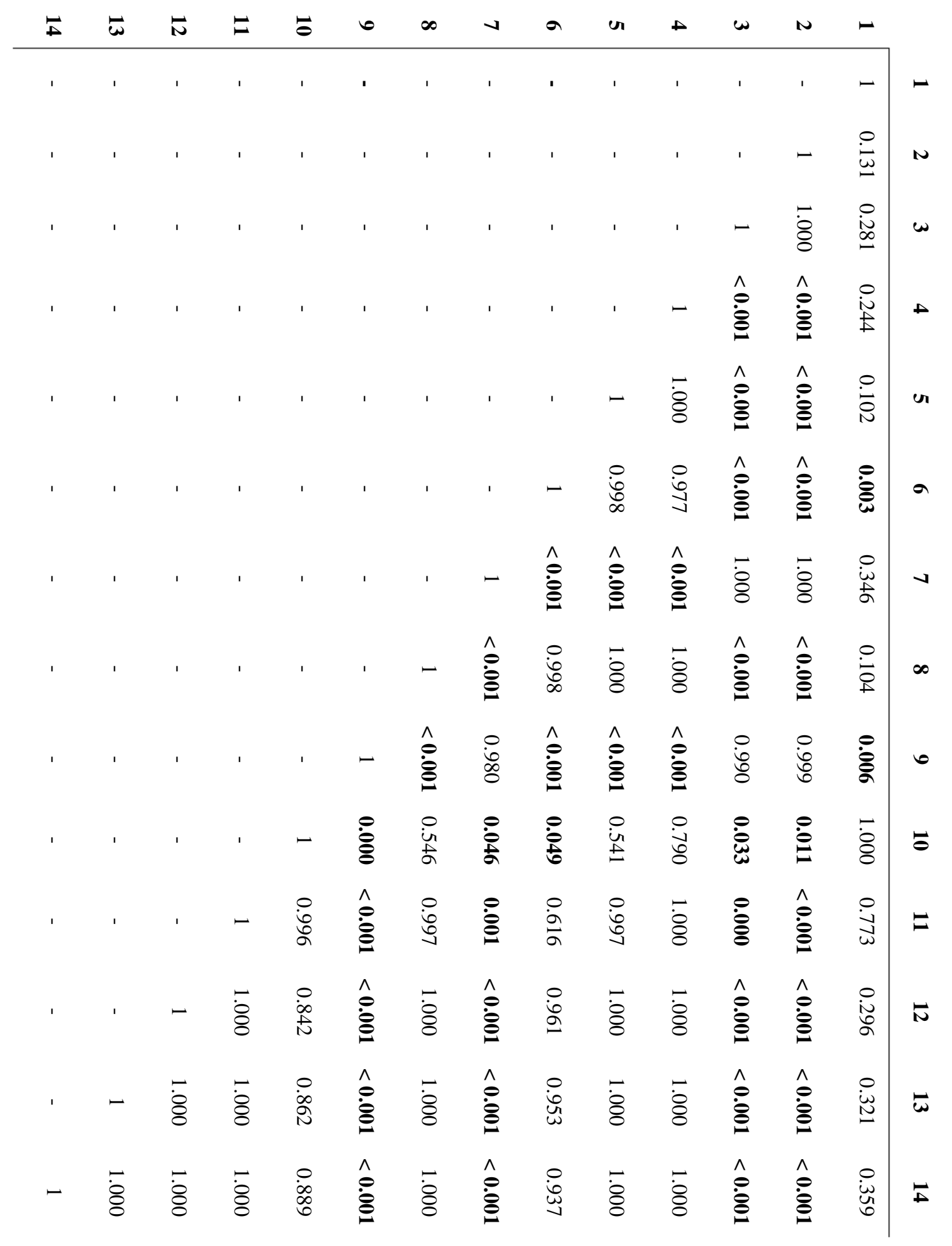


Figure 1. (A) Study site in Bird Rock, La Jolla, CA, USA ( $32^{\circ} 48^{\prime} 33^{\prime \prime}$ N, $117^{\circ}$ 16' 07" W) (Google Earth 2016). (B) Large white boxes and numbers indicate locations within the intertidal where paired larval traps (in blue) and settlement plates (in orange) were deployed during summer 2014 and 2015. (C) Numbers indicate Chthamalus fissus settlement plate deployment locations on boulders (in orange) and where adult surveys (in red) were conducted December 2014 to December 2016. 

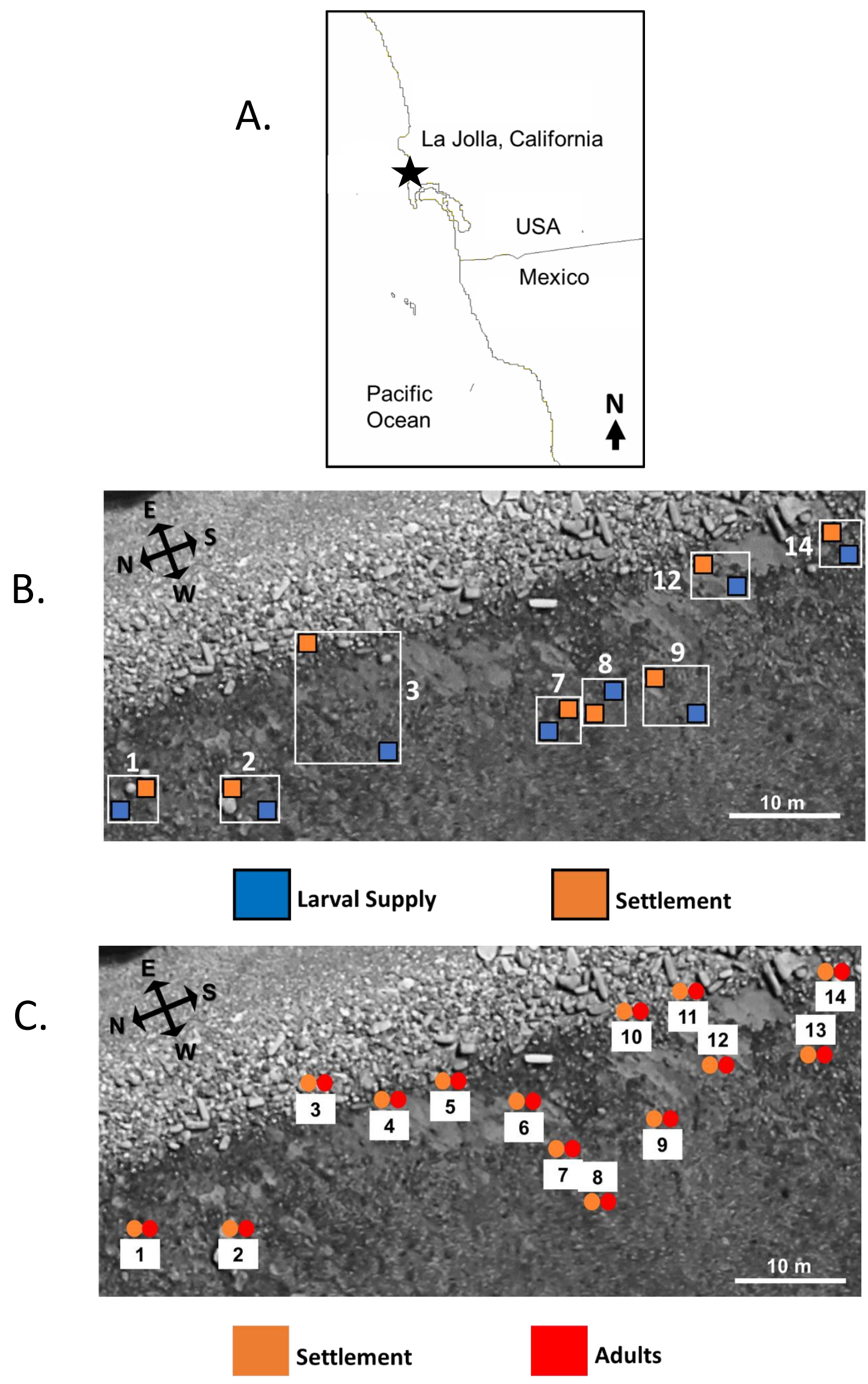
Figure 2. Time series for Chthamalus fissus larval supply (\# cyprids / trap) for (A): 2014, (B): 2015a, (C): 2015b and for Chthamalus fissus settlement (\# settlers $/ \mathrm{cm}^{2} \mathrm{~d}$ ) for (D): 2014, (E): 2015a, (F): 2015b. Please note 2014 included June $16^{\text {th }}, 2014$ to July $16^{\text {th }}, 2014 ; 2015$ a included April $24^{\text {th }}, 2015$ to June $5^{\text {th }}, 2015$; and $2015 \mathrm{~b}$ included June $6^{\text {th }}, 2015$ to August $2^{\text {nd }}, 2015$. 

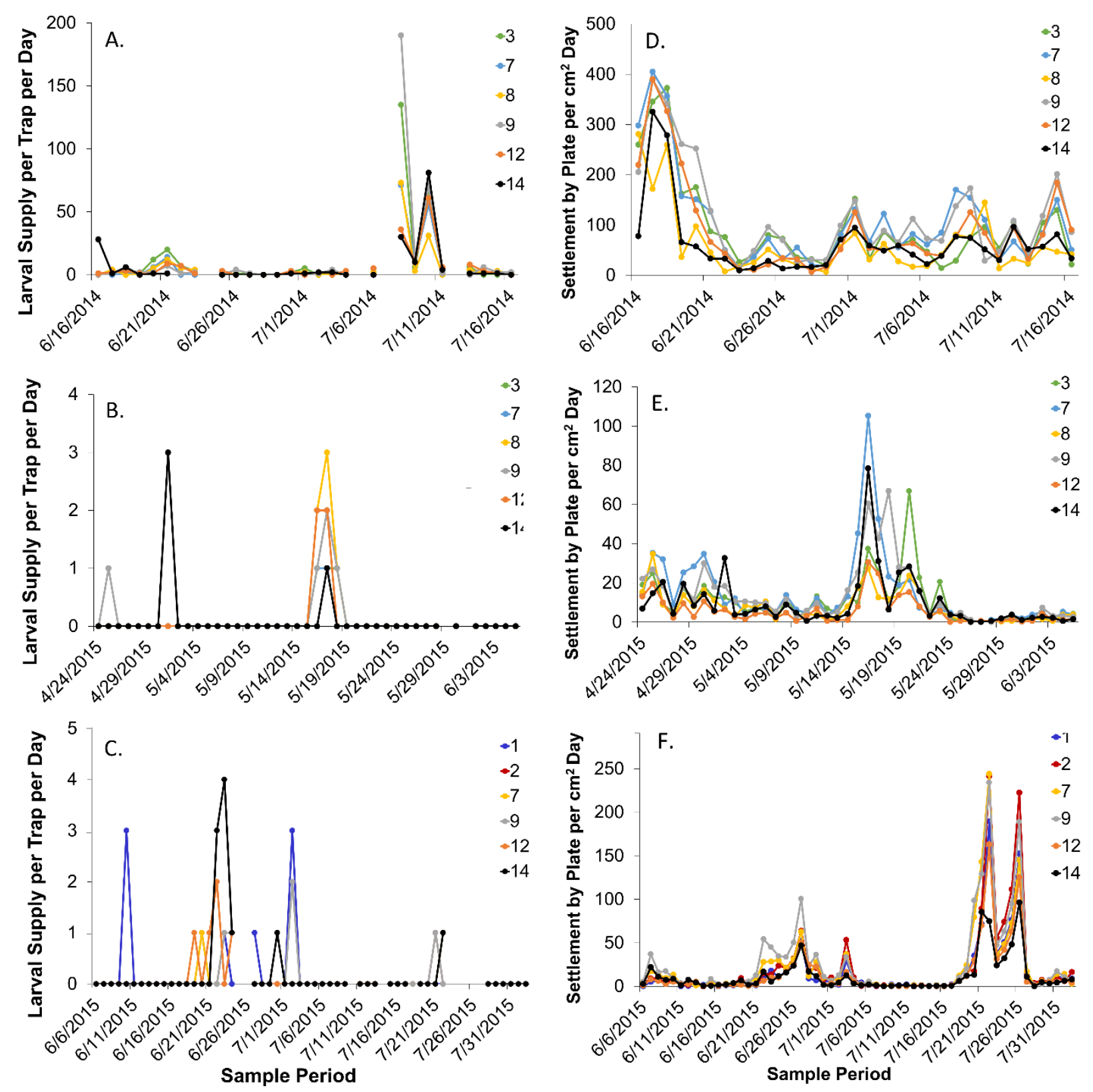
Figure 3. Average $\log (\mathrm{x}+1)$ transformed Chthamalus fissus larval supply (\# cyprids / trap) versus average $\log (\mathrm{x}+1)$ Chthamalus fissus settlement (\# settlers / $\mathrm{cm}^{2}$ d) by location for (A) 2014 (June $6^{\text {th }}, 2014$ to July 16 ${ }^{\text {th }}, 2014$ ), (B) 2015a (April 24 $4^{\text {th }}, 2015$ to June $5^{\text {th }}, 2015$ ), (C) 2015b (June $6^{\text {th }}, 2015$ to August $2^{\text {nd }}$, 2015). The error bars have been excluded for ease of visualization and the adjusted $\mathrm{R}^{2}$ values are given for each period, along with the associated $\mathrm{p}$-value when it is significant. 
2014
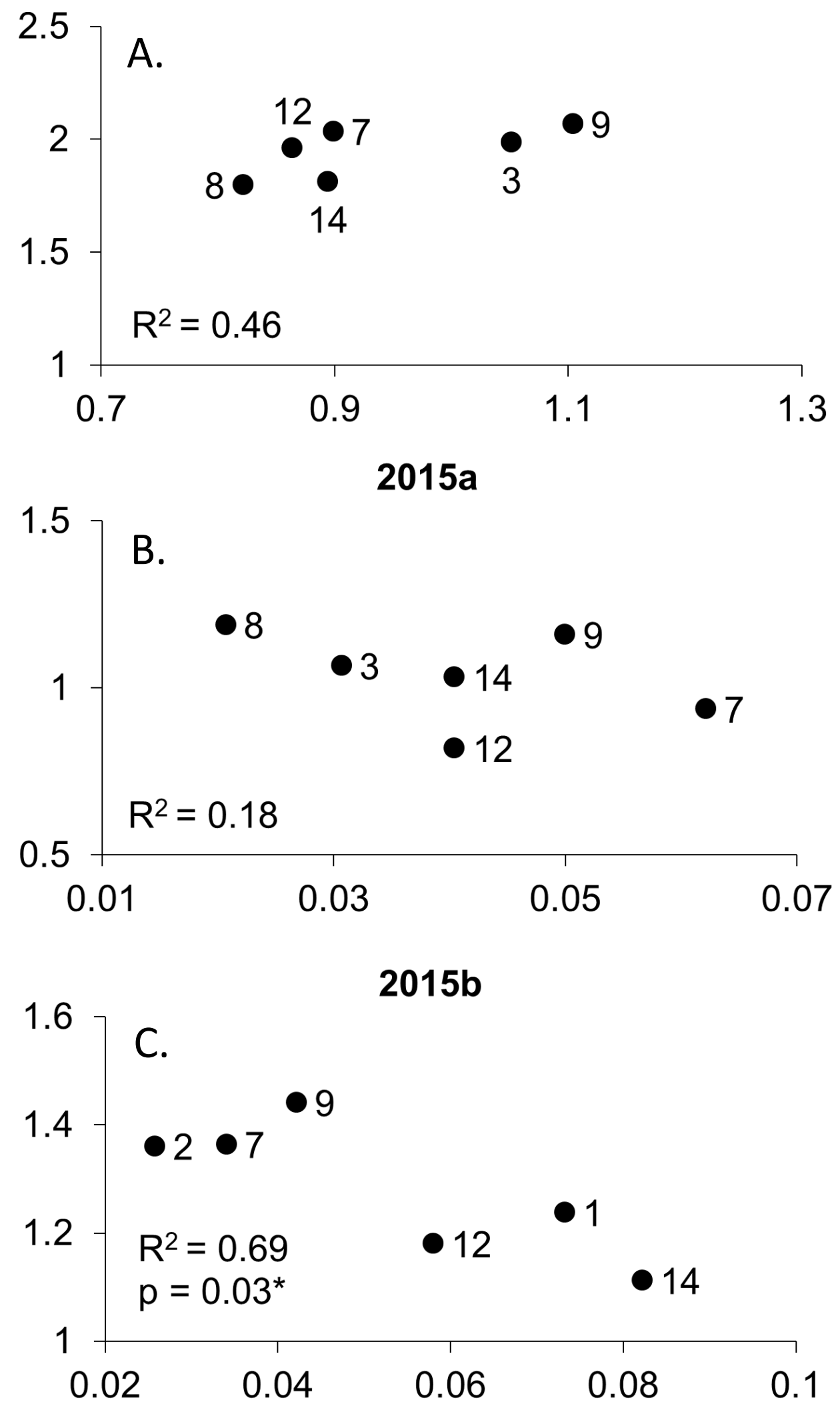
Figure 4. Average proportion of settlement of Chthamalus fissus from 2014-2016 by plate with respect to elevation (A) and distance to water (B). Only dates when 12 plates were deployed were used, points are labeled by plate 

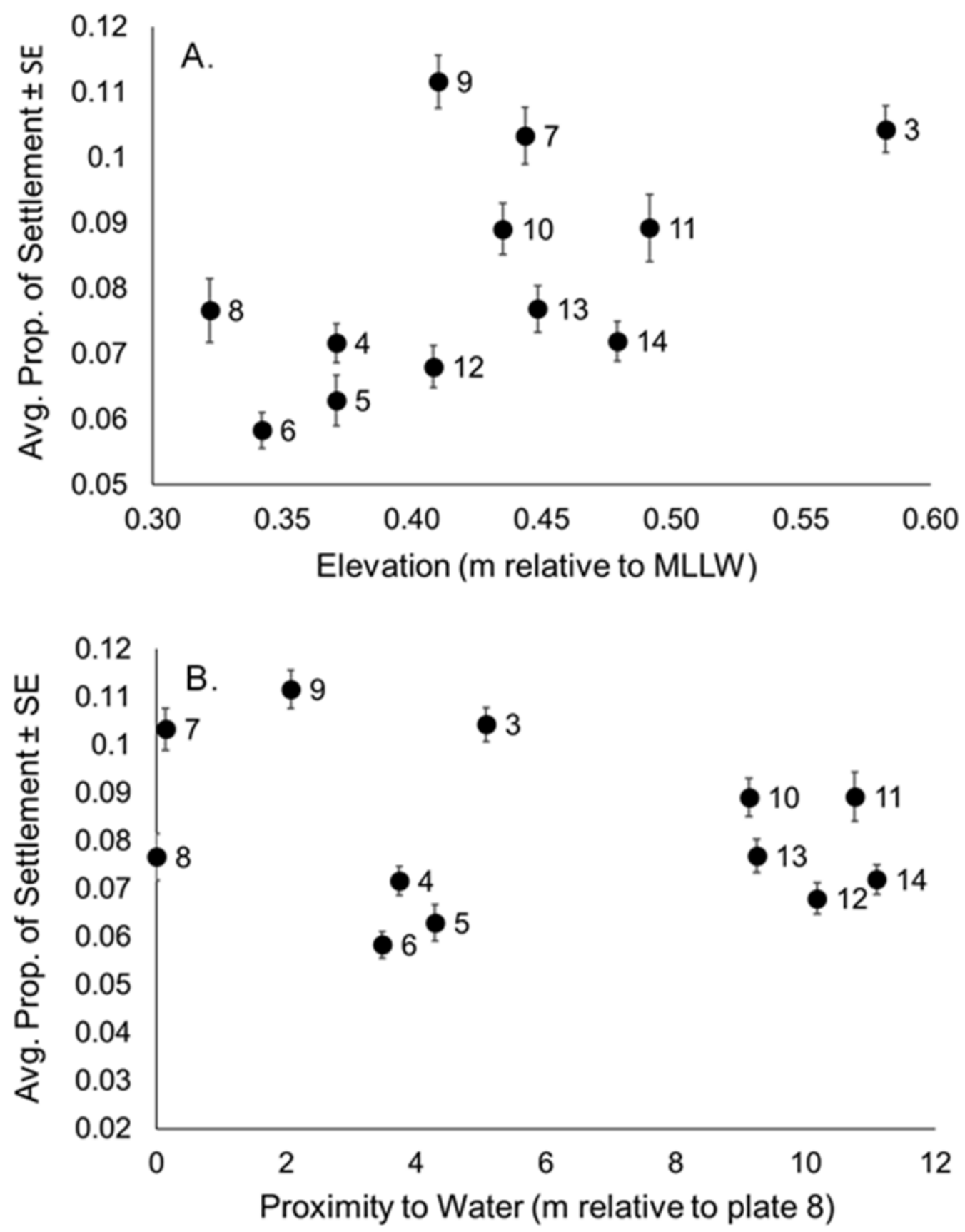
Figure 5. Monthly-averaged Chthamalus fissus settlement (A); and monthlyaveraged percent free space (B), percent cover of live barnacles (C), percent cover of dead barnacles (D), and percent cover of algae (E) from December 2014 to December 2016. Panels A-E included \pm SE for $n=14$ plates across 24 months. May 2015, September 2015, and May 2016 were excluded from panel A due to incomplete settlement data, $\mathrm{n}=21$ months. 

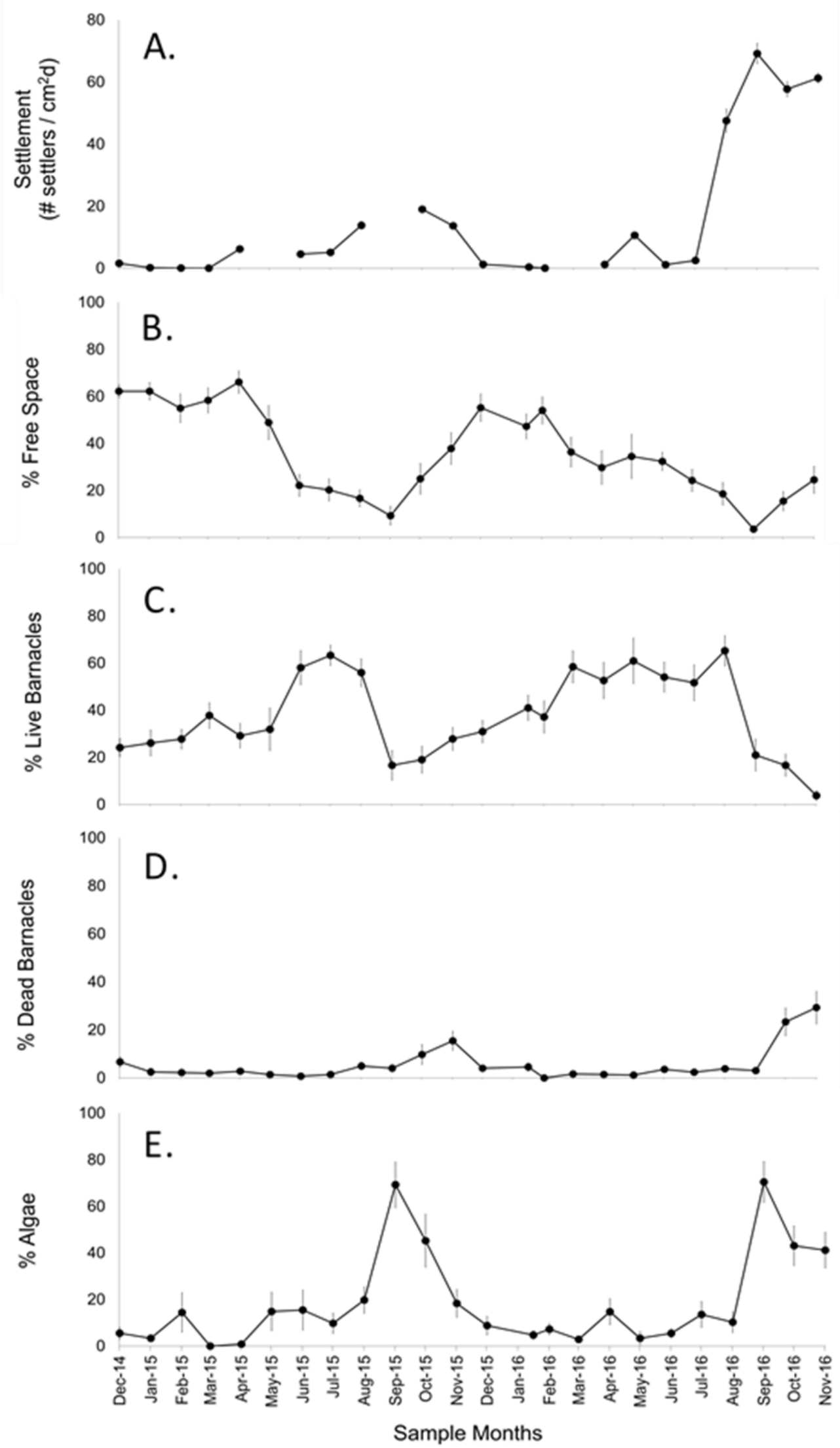
Figure 6. Monthly-averaged Chthamalus fissus settlement versus monthlyaveraged percent free space for each settlement plate (numbers 1-14) from December 2014 to December 2016, $\mathrm{n}=21$ months. 


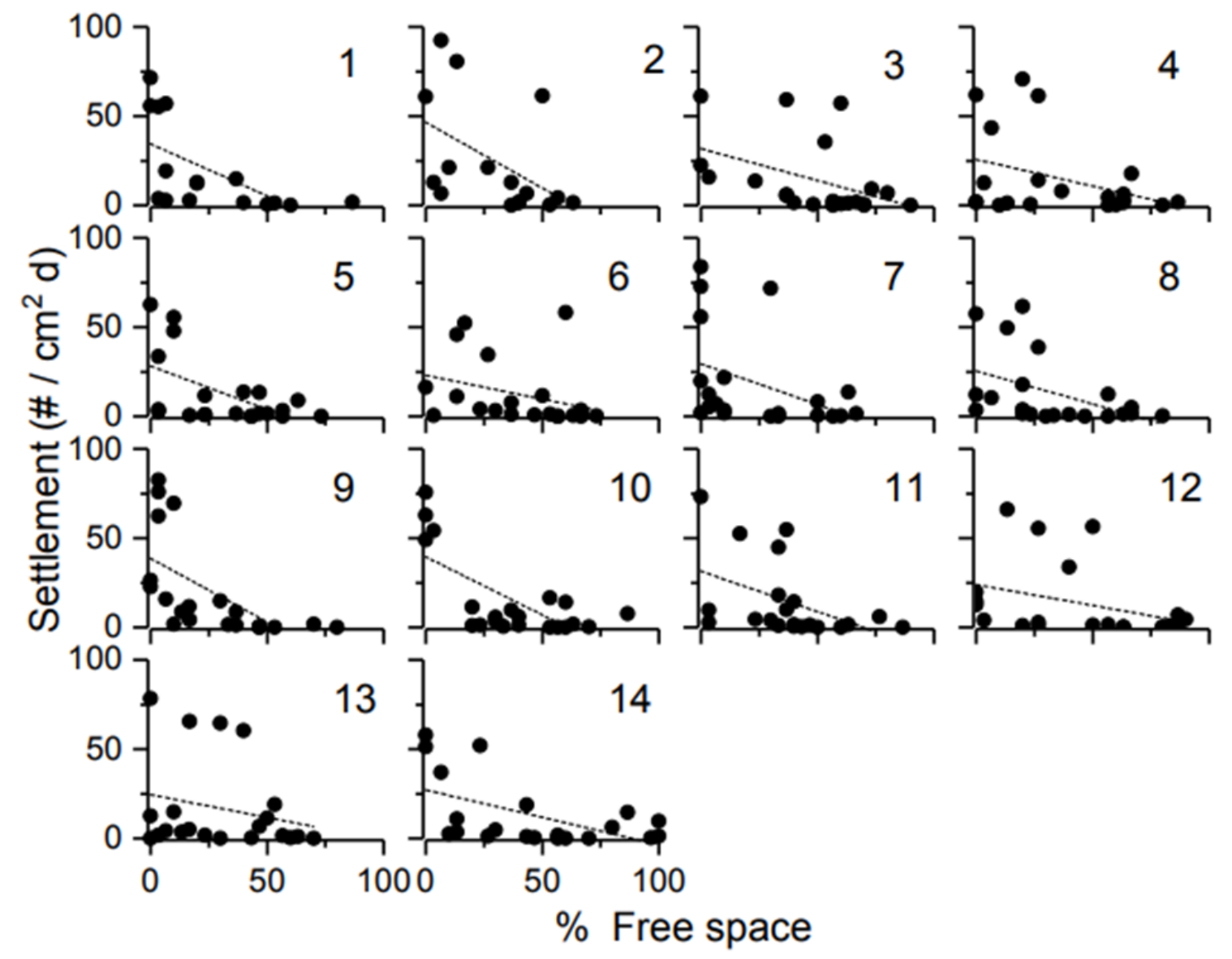


Figure 7. Log-transformed monthly-averaged (over all plates) Chthamalus fissus settlement compared to monthly-averaged percent free space (over all plates), $\mathrm{n}=$ 21 months $(\mathrm{p}<<0.001)$. 


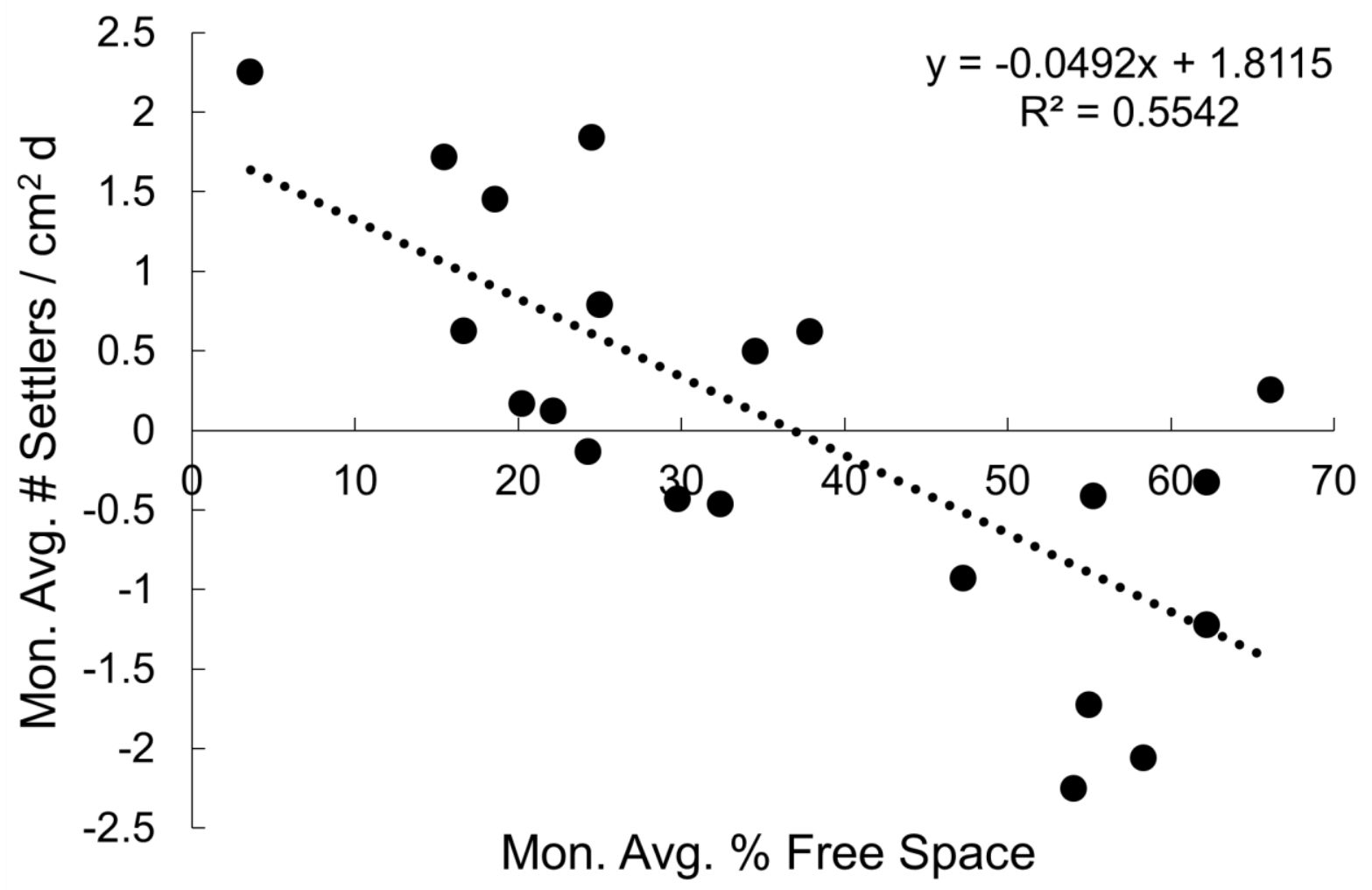


Figure 8. Monthly-averaged percent free space compared to monthly-averaged percent cover of live barnacles (A); hyperbolic arcsin-transformed percent cover of dead barnacles (B); and hyperbolic arcsin-transformed percent cover of algae (C), $\mathrm{n}=21$ months. Panels B and C zoomed in on the $\mathrm{x}$-axis for ease of visualization 

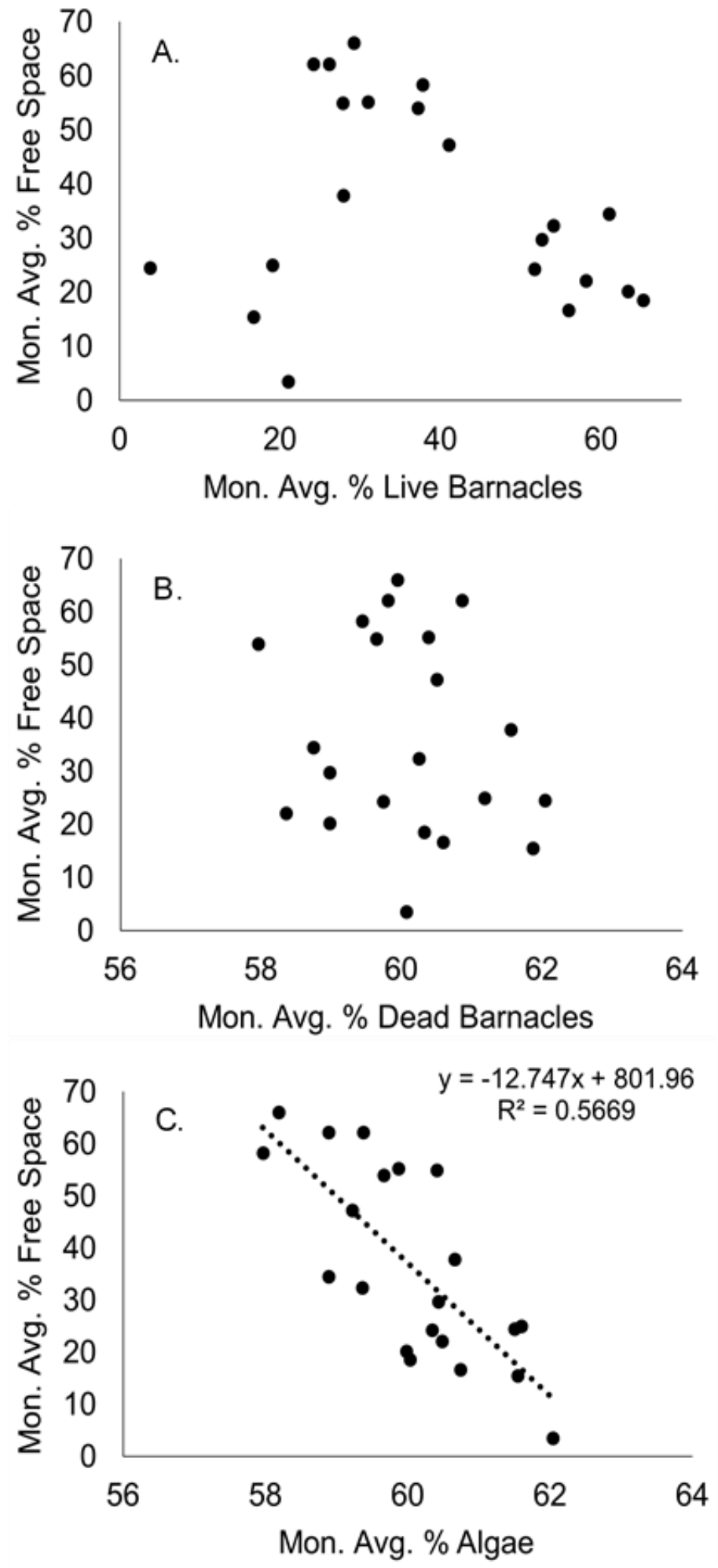
Figure 9. Average Chthamalus fissus settlement \pm SE (A), and average proportion of settlement $\pm \mathrm{SE}$ (B) for each plate grouped by dates where 12 plates (April $24^{\text {th }}, 2014$ to June $5^{\text {th }}, 2015, \mathrm{n}=217$ days per plate) and 14 plates (June $6^{\text {th }}$, 2015 to December $15^{\text {th }}, 2015, \mathrm{n}=156$ days per plate) were deployed. The correlation between average proportion of settlement \pm SE per plate in 2014 ( $\mathrm{n}=$ 173 days per plate) versus in $2015(\mathrm{n}=200$ days per plate) $(\mathrm{C})$. The black point is to distinguish between two overlapping points. Plates 1 and 2 were omitted to compare plates during the same time interval. 

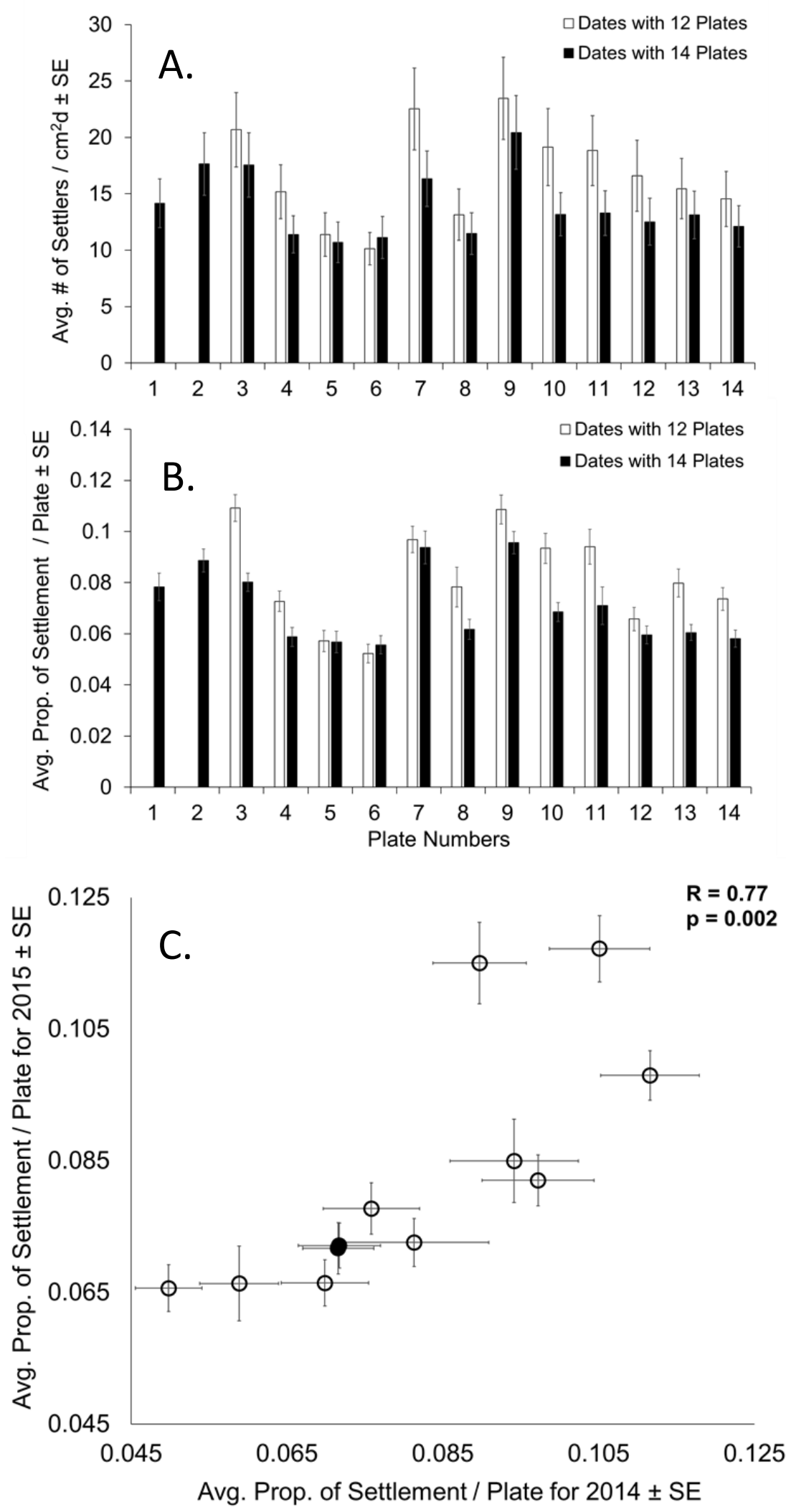
Figure 10. Average rank of Chthamalus fissus settlement for 12 plates ( $\mathrm{n}=217$

days per plate) $(A)$, and 14 plates $(n=156$ days per plate) $(B)$ ordered from smallest to largest values. The arrows indicate which plates were similar, according to pairwise comparisons using Nemenyi's multiple comparison test. 


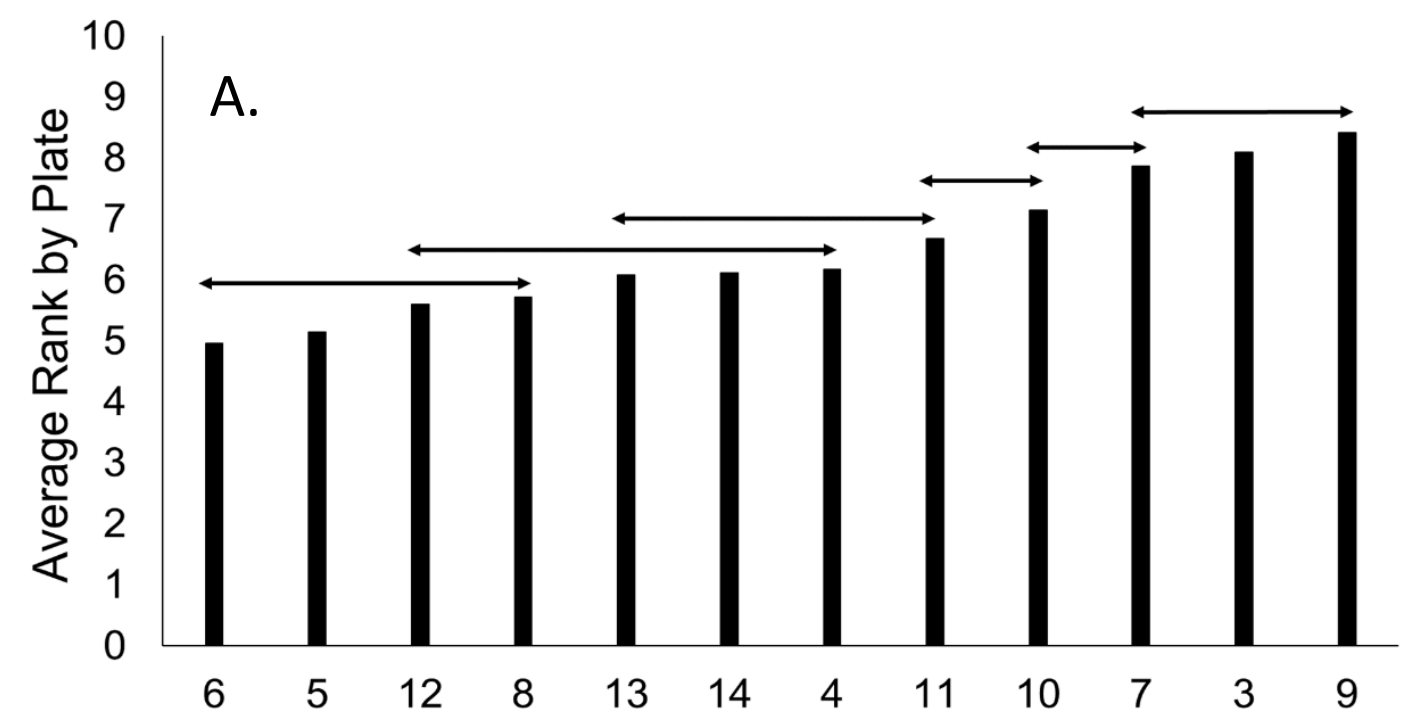

Plate Numbers

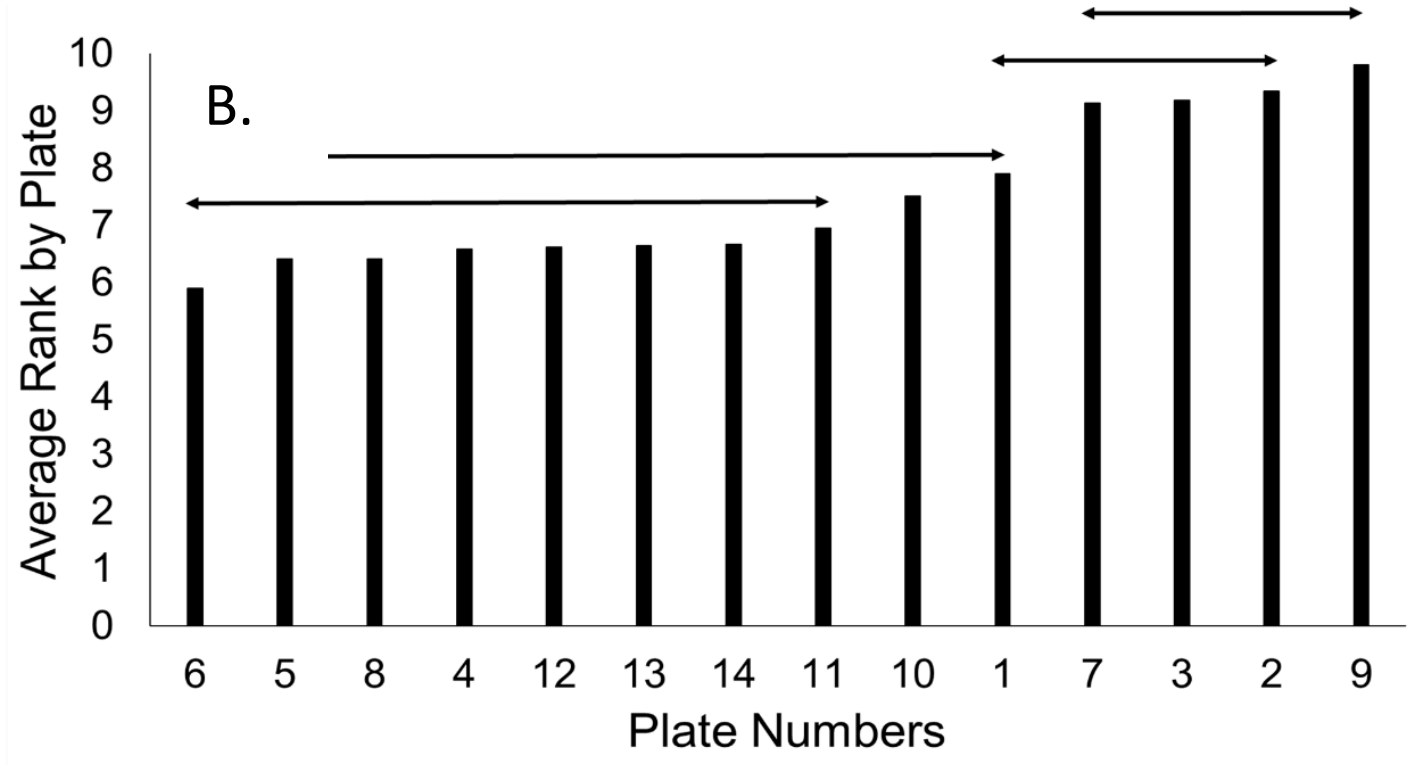




\section{CHAPTER 3:}

\section{General Thesis Conclusions and Future Directions}

Through our two-year project, we concluded that the environment of the rocky intertidal plays a prominent role in shaping the processes that result in Chthamalus fissus settlement. Therefore, when studying the settlement of benthic invertebrate populations, the habitat dynamics (e.g., available space, hydrodynamics) and larval behavior must be considered. It is important to consider the role each factor plays in shaping settlement to have a holistic understanding of how benthic invertebrate populations develop. A mix of short(monthly to seasonal scale) to long-term studies (yearly scale) must continue to allow for observations of the process of settlement and the factors which influence this process across small (rocky intertidal localities) to larger (regions) spatial scales through time.

In taking this multi-scaled approach, researchers will further understand the environmental dynamics that result in alterations to settlement patterns. Some studies such as Valencia-Gasti and Ladah (2016) observed settlement on a local ( 1 km scale), and found that, despite homogenous patterns of larval transport and subsequent settlement, slight spatial changes in settlement may have resulted from variations in geomorphology and bathymetry influencing the differences in larval transport to sites in close proximity. Other studies have highlighted at scales of $\sim 100 \mathrm{~m}$, spatial variability in settlement that may also be influenced by larval searching behavior and the availability of space, in addition to temporal variability influenced by differences in the larval pool due to variations in 
transport mechanisms across time (Pineda 1994). There have been studies that focused on settlement and recruitment variation from a meso-scale (regional) to small-scale (locality). Such studies include Lagos et al. (2005) who found that Chthamalus species' settlement variation was correlated with indices (SST) related to changes in transport (topographically modified upwelling) at a regional or meso-scale. Other studies have investigated the influence of climatic factors on recruitment from regional to ocean basin scales across long-term time series (Menge et al. 2011). Across a 20-year period, Menge et al. (2011) observed that upwelling and climatic events explained $\sim 40 \%$ of the variation in recruitment across a regional scale $(\sim 250 \mathrm{~km})$, with the additional variation explained by local processes $(\sim 1 \mathrm{~km}$ to $100 \mathrm{~s}$ of $\mathrm{m})$ relating to transport and post-settlement factors. These examples indicate that a multitude of factors shape the settlement and ultimate recruitment of benthic invertebrate populations. Therefore, these factors must all be considered with regards to the weight of their influence in formulating the mosaic of settlement processes which shape benthic invertebrate populations within specific coastal communities.

Following the life history stages of $C$. fissus across multiple spatial scales begins to resolve the influences on settlement during larval development. To gain a fundamental understanding of the connection between offshore larval development in the coastal ocean to onshore juvenile and adult benthic populations requires investigating the biological and physical processes that shape larval dispersal and settlement (Cowen and Sponaugle 2009). The processes which warrant investigation following our study include mechanisms of larval 
transport leading to dispersal, hydrodynamic conditions, and larval searching behavior during settlement, and post-settlement mortality. To understand the influence of these processes on settlement, the reproductive connectivity of a population, defined as the exchange of individuals that ultimately reproduce, must be observed to understand the minimum number of recruits a population requires to ecologically sustain itself across time (Pineda et al. 2007). For example, high recruitment has been observed (Hughes et al. 2000) when the proportion of reproductive Acropora spp. individuals was close to $100 \%$. Additionally, where Mytilus spp. were tracked through an elemental tracer, they were found closer ( 20-30 km) to their original spawning site than initially expected (Becker et al. 2007). These types of studies allowed researchers to examine the interactions between life history stages that connect a population. Extending our study would allow for the examination of barnacle reproductive patterns that supply new recruits to sustain populations within intertidal communities as well as the biological and physical factors which influence these patterns.

To further my study, investigating the reproductive connectivity of $C$. fissus populations within Bird Rock may help inform the spatial boundaries of local populations from their nearshore development to onshore settlement. By informing these spatial boundaries around the reproductive connectivity of benthic invertebrate populations, more effective management of coastal ecosystems with precious resources (e.g., locations for sustainable local fisheries and ecotourism) is possible (Roberts 1997, Becker et al. 2007). The potential to implement spatial boundaries has been highlighted in Gerber et al. (2011), which 
describes the conceptual framework for considering the influence of dispersal and other factors on demographic models which inform the spatial dynamics of a population. This framework for creating spatial boundaries based on the spatial dynamics of populations is one consideration for coastal management or protection (Sale et al. 2005). Managing marine protected areas (MPAs) requires an ecosystem-based management approach (Halpern et al. 2010). Often MPAs are structured with central regions where removal of any physical or biological components is prohibited and surrounding these regions are buffer zones where removal of these components is permitted (Long et al. 2015, DiFranco et al. 2016). The idea of ecosystem-based management is the allowance of the regulated use of buffer zones within MPAs for socio-economic sustainable activities following specific guidelines which satisfy conservation aims and allow for local economies (i.e. tourism and fisheries) and coastal ecosystems to both be sustained long-term (Long et al. 2015, DiFranco et al. 2016). By maintaining strict enforcement of ecosystem-based management, restrictions of no-take and buffer zones within MPAs, coastal regions with high productivity and biodiversity can be better protected from external, anthropogenically-related threats (Jones et al. 2007). Therefore, to maintain a healthier longevity of coastal ecosystems (e.g., rocky intertidal, coral reef, and seagrass communities), the larval transport and dispersal patterns of populations with planktonic larvae must be considered to understand the boundaries of population connectivity to establish MPAs. 


\section{LITERATURE CITED}

Alexander SE, Roughgarden J (1996) Larval transport and population dynamics of intertidal barnacles: a coupled benthic/oceanic model. Ecol Monogr 66(3): 259-275

Barnes H, Barnes M (1957) Resistance to desiccation in intertidal barnacles. Science 126(3269): 358

Barth JA, Menge BA, Lubchenco J, Chan F, Bane JM, Kirincich AR, McManus MA, Nielsen KJ, Pierce SD, Washburn L (2007) Delayed upwelling alters nearshore coastal ecosystems in the northern California current. Proc Natl Acad Sci USA 104(10): 3719-3724

Basilio A, Searcy S, Thompson AR (2017) Effects of the Blob on settlement of spotted sand bass, Paralabrax maculatofasciatus, to Mission Bay, San Diego, CA. PLOS https:doi.org/10/1371/journal.pone.0188449

Beermann AJ, Ellrich JA, Molis M, Scrosati RA (2013) Effects of seaweed canopies and adult barnacles on barnacle recruitment: the interplay of positive and negative influences. J Exp Mar Biol Ecol 448: 162-170

Becker BJ, Levin LA, Fodrie J, McMillan PA (2007) Complex larval connectivity patterns among invertebrate populations. Proc Natl Acad Sci USA 104(9): 3267-3272

Berntsson KM, Jonsson PR, Larsson AI, Holdt S (2004) Rejection of unsuitable substrata as a potential driver of aggregated settlement in the barnacle Balanus improvisus. Mar Ecol Prog Ser 275: 199-210. 
Bertness MD, Gaines SD, Stephens EG, Yund PO (1992) Components of recruitment in populations of the acorn barnacle Semibalanus balanoides (Linnaeus). J Exp Mar Biol Ecol 156(2): 199-215

Bertness MD, Gaines SD (1993) Larval dispersal and local adaptation in acorn barnacles. Evolution 47(1): 316-320

Bertness MD, Gaines SD, Whale RA (1996) Wind-driven settlement patterns in the acorn barnacle Semibalanus balanoides. Mar Ecol Prog Ser 137: 103-110

Beukema JJ, Flach EC (1995) Factors controlling the upper and lower limits of the intertidal distribution of two Corophium species in the Wadden Sea. Mar Ecol Prog Ser 125: 117-126

Brandon JL, Rokop FJ (1985) Life between the Tides: The Natural History of the Common Seashore Life of Southern California. American Southwest Publishing Company of San Diego, California.

Broitman BR, Blanchette CA, Gaines SD (2005) Recruitment of intertidal invertebrates and oceanographic variability at Santa Cruz Island, California. Limnol Oceanogr 50(5): 1473-1479

Brown SK, Roughgarden J (1985) Growth, morphology, and laboratory culture of larvae of Balanus glandula (Cirripedia: Thoracica). J Crustac Biol 5(4): $574-590$

Brown KM, Swearingen DC (1998) Effects of seasonality, length of immersion, locality and predation on an intertidal fouling assemblage in the Northern Gulf of Mexico. J Exp Mar Biol Ecol 225(1): 107-121 
Burnham KP, Anderson DR (2002) Model selection and multi-model inference: a practical information-theoretic approach, second edition. Springer-Verlag New York Inc., New York, NY, USA

Caffey HM (1985) Spatial and temporal variation in settlement and recruitment of intertidal barnacles. Ecol Mono 55: 313-332

Carlon DB, Olson RR (1993) Larval dispersal distance as an explanation for adult spatial pattern in two Caribbean reef corals. J Exp Mar Biol Ecol 173(2): $247-263$

Chabot R, Bourget E (1988) Influence of substratum heterogeneity and settled barnacle density on the settlement of cypris larvae. Mar Biol 97(1): 45-56

Chen HN, Todd CD, Williams GA, Benny CKK (2013) A new passive plankton trap to quantify the supply of crustacean and molluscan larvae to rocky shores. J Exp Mar Biol Ecol 441: 80-89

Connell JH (1961a) Effects of competition, predation by Thais (Nucella) lapillus, and other factors on natural populations of the barnacle Balanus balanoides. Ecol Monogr 31(1): 61-104

Connell JH (1961b) The influence of interspecific competition and other factors on the distribution of the barnacle Chthamalus stellatus. Ecology 42(4): 710723

Connell JH (1970) A predator-prey system in the marine intertidal region. I. Balanus glandula and several predatory species of Thais. Ecol Mono 40(1): $49-78$ 
Connell JH (1985) The consequences of variation in initial settlement versus postsettlement mortality in rocky intertidal communities. J Exp Mar Biol Ecol 93(1-2):11-45

Connolly SR, Roughgarden J (1998) A latitudinal gradient in northeast Pacific intertidal community structure: evidence for an oceanographically based synthesis of marine community theory. Am Nat 151(4): 311-326

Cowen RK, Sponaugle S (2009) Larval dispersal and marine population connectivity. Ann Rev Mar Sci 1: 443-466

Crimaldi JP, Thompson JK, Rosman JH, Lowe RJ, Koseff JR (2002) Hydrodynamics of larval settlement: the influence of turbulent stress events at potential recruitment sites. Limnol Oceanogr 47(4): 1137-1151

Crisp DJ, Knight-Jones EW (1953) The mechanism of aggregation in barnacle populations. J Anim Ecol 22(2): 360-362

Crisp DJ (1955) The behavior of barnacle cyprids in relation to water movement over a surface. J Exp Biol 32: 569-590

Crisp DJ, Meadows PS (1962) The chemical basis of gregariousness in cirripedes. Proc R Soc B 156(965): 500-520

Crisp DJ (1974) Factors influence the settlement of marine invertebrate larvae. In: Grant PT, Mackie AM (Eds.), Chemoreception in marine organisms. Academic Press, London, pp. 177-265

Cruz T, Castro JJ, Delany J, McGrath D, Myers AA, O’Riordan RM, Power AM, Rabaca J, Hawkins SJ (2005) Tidal rates of settlement of the intertidal barnacles Chthamalus stellatus and Chthamalus montagui in western 
Europe: the influence of the night/day cycle. J Exp Mar Biol Ecol 318(1): $51-60$

Dayton PK (1971) Competition, disturbance, and community organization: the provision and subsequent utilization of space in a rocky intertidal community. Ecol Monogr 41(4): 351-389

DiFranco A, Thiriet P, Di Carlo G, Dimitriadis C, Francour P, Gutiérrez NL, de Grissac AJ, Koutsoubas D, Milazzo M, Otero MM, Piante C, Plass-Johnson J, Sainz-Trapaga S, Santarossa L, Tudela S, Guidetti P (2016) Five key attributes can increase marine protected areas performance for small-scale fisheries management. Sci Rep 6: 38135

Eckman JE (1996) Closing the larval loop: linking larval ecology to the population dynamics of marine benthic invertebrates. J Exp Mar Biol Ecol 200(1-2): $207-237$

Elbourne ED, Veater RA, Clare AS (2008) Interaction of conspecific cues in Balanus amphirite Darwin (Cirripedia) settlement assays: continued argument for the single-larva assay. Biofouling: The Journal of Bioadhesion and Biofilm Research 24(2): 87-96

Farrell TM, Bracher D, Roughgarden J (1991) Cross-shelf transport causes recruitment to intertidal populations in central California. Limnol Oceanogr 36(2): 279-288

Foster BA (1971) Desiccation as a factor in the intertidal zonation of barnacles. Mar Biol 8: 12-29 
Fraschetti S, Giangrande A, Terlizzi A, Boero F (2002) Les événements de pré- et post-installation larvaire dans la dynamique des communautés benthiques. Oceanologica Acta 25(6): 285-295

Gaines S, Brown S, Roughgarden J (1985) Spatial variation in larval concentrations as a cause of spatial variation in settlement for the barnacle, Balanus glandula. Oecologia 67(2): 267-272

Gaines SD, Roughgarden J (1985) Larval settlement rate: a leading determinant of structure in an ecological community of the marine intertidal zone. Proc Natl Acad Sci USA 82(11): 3707-3711

Gawarkiewicz GG, Monismith SG, Largier J (2007) Observing larval transport processes affecting population connectivity: progress and challenges. Oceanography 20(3): 40-53

Gerber LR, Heppell SS, Ballantyne F, Sala E (2011) The role of dispersal and demography in determining the efficacy of marine reserves. Can J Fish Aquat Sci 62(4): 863-871

Google Earth (2016) Google Earth Pro. www.google.com/earth/desktop (accessed June 1st, 2017 to August $1^{\text {st }}, 2017$ )

Halpern BS, Lester SE, McLeod KL (2010) Placing marine protected areas onto the ecosystem-based management seascape. Proc Natl Acad Sci USA 107(43): 18312-18317

Hatton H (1938) Essais de bionomie explicative sur quelques espèces intercotidales d'algues et d'animaux. Annls Inst Océanogr 17: 241-348 
Haury L, Wiebe P (1982) Fine-scale multi-species aggregations of oceanic zooplankton. Deep-sea Res 29: 915-921

Hawkins SJ, Hartnoll RG (1982) Settlement patterns of Semibalanus balanoides (L.) in the Isle of Man (1977-1981). J Exp Mar Biol Ecol 62: 271-283

Hills JM, Thomason JC, Milligan JL, Richardson T (1998) Do barnacle larvae respond to multiple settlement cues over a range of spatial scales? Hydrobiologia 375 (376): 101-111

Hines AH (1978) Reproduction in three species of intertidal barnacles from Central California. Biol Bull 154: 262-281

Hines AH (1979) The comparative reproduction ecology of three species of intertidal barnacles. p.213 In, Reproductive ecology of marine invertebrates (Stancyk, ed.) U South Carolina Press, Columbia

Høeg JT, Møller OS (2006) When similar beginnings lead to different ends: Constraints and diversity in cirripede larval development. Invertebr Repr Dev 49(3): 125-142

Hoffmann V, Pfaff MC, Branch GM (2012) Spatio-temporal patterns of larval supply and settlement of intertidal invertebrates reflect a combination of passive transport and larval behavior. J Exp Mar Biol Ecol 418-419: 83-90 Hughes TP, Baird AH, Dinsdale EA, Moltschaniwskyj NA, Pratchett MS, Tanner JE, Willis BL (2000) Supply-side ecology works both ways: the link between benthic adults, fecundity, and larval recruits. Ecology 81(8): 22412249 
Iles AC, Gouhier TC, Menge BA, Stewart JS, Haupt AJ, Lynch MC (2011) Climate-driven trends and ecological implications of event-scale upwelling in California Current System. Global Change Biol: doi: 10.1111/j.1365$2486.2011 .02567 x$

Jacinto D, Cruz T (2008) Tidal settlement of the intertidal barnacles Chthamalus spp. in SW Portugal: interaction between diel and semi-lunar cycles. Mar Ecol Prog Ser 366: 129-135

Jarrett JN (1997) Temporal variation in substratum specificity of Semibalanus balanoides (Linnaeus) cyprids. J Exp Mar Biol Ecol 211(1): 103-114

Jeffrey CJ (2000) Settlement in different-sized patches by the gregarious intertidal barnacle Chamaesipho tasmanica Foster and Anderson in New South Wales. J Exp Mar Biol Ecol 252: 15-26

Jenkins SR (2005) Larval habitat selection, not larval supply, determines settlement patterns and adult distribution in two chthamalid barnacles. J Anim Ecol 74(5): 893-904

Jernakoff P, Fairweather PG (1985) An experimental analysis of interactions among several intertidal organisms. J Exp Mar Biol Ecol 94(1-3): 71-88

Jones GP, Srinivasan M, Almany GR (2007) Population connectivity and conservation of marine biodiversity. Oceanography 20(3): 100-111

Jonsson PR, Berntsson KM, Larsson A (2004) Linking larval supply to recruitment: flow-mediated control of initial adhesion of barnacle larvae. Ecology 85: 2850-2859 
Kent A, Hawkins SJ, Doncaster P (2003) Population consequences of mutual attraction between settling and adult barnacles. J Anim Ecol 72: 941-952

Koehl MRA (2007) Mini review: hydrodynamics of larval settlement into fouling communities. Biofouling 23(5): 357-368

Lagos NA, Navarrete SA, Liz FV, Masuero A, Castilla JC (2005) Meso-scale spatial variation in settlement and recruitment of intertidal barnacles along the coast of central Chile. Mar Ecol Prog Ser 290: 165-178

Lewin R (1986) Supply-side ecology. Science 234(4772): 25-27

Long RD, Charles A, Stephenson RL (2015) Key principles of marine ecosystembased management, Mar Pol 57: 53-60

Lo-Yat A, Simpson SD, Meekan M, Lecchini D, Martinez E, Galzin R (2011) Extreme climatic events reduce ocean productivity and larval supply in a tropical reef ecosystem. Global Change Biol 17(4): 1695-1702

Lubchenco J, Menge BA (1978) Community development and persistence in a low rocky intertidal zone. Ecol Monogr 48(1): 67-94

Luckens PA (1975) Predation and intertidal zonation of barnacles at Leigh, New Zealand. N Z J Mar Freshw Res 9(3): 355-378

Lundquist CJ, Botsford LW, Morgan LE, Diehl JM, Lee T, Lockwood DR, Pearson EL (2000) Effects of El Niño and La Niña on local invertebrate settlement in northern California. CALCOFI Rep. 41: 167-176

Ma H (2005) Spatial and temporal variation in surf clam (Spisula solidissima) larval supply and settlement on the New Jersey inner shelf during summer upwelling and downwelling. Estuar Coast Shelf Sci 62: 41-53 
Maclsaac HJ, Sprules WG, Leach JH (1991) Ingestion of small-bodied zooplankton by zebra mussels (Dreissena polymorpha): Can cannibalism on larvae influence population dynamics? 48(11): 2051-2060

Marshall DJ, Styan C, McQuaid CD (2009) Larval Supply and Dispersal. Biofouling 11, DOI: 10.1007/b76710_11

Matsumura K, Qian PY (2014) Larval vision contributes to gregarious settlement in barnacles: adult red fluorescence as a possible visual signal. J Exp Biol 217: $743-750$

Mcclatchie S, Jacox M, Goericke R, Leising A, Schneider S, Thompson AR, Golightly RT, Gomez-Valdes J (2016) State of the California Current 201516: Comparisons with the 1997-98 El Niño. California Cooperative Oceanic Fisheries Investigations Report 57: 1-57

Menge BA (1983) Components of predation intensity in the low zone of the New England rocky intertidal region. Oecologia 58(2): 141-155

Menge BA, Chan F, Nielsen KJ, Lorenzo ED, Lubchenco J (2009) Climatic variation alters supply-side ecology: impact of climate patterns on phytoplankton and mussel recruitment. Ecol Monogr 79(3): 379-395

Menge BA, Gouhier TC, Freidenburg T, Lubchenco J (2011) Linking long-term, large-scale climatic and environmental variability to patterns of marine invertebrate recruitment: Toward explaining "unexplained" variation. J Exp Mar Biol Ecol 400(1-2): 236-249 
Minchinton TE, Scheibling RE (1991) The influence of larval supply and settlement on the population structure of barnacles. Ecology 72(5): 18671879

Minchinton TE, Scheibling RE (1993) Free space availability and larval substratum selection as determinants of barnacle population structure in a developing rocky intertidal community. Mar Ecol Prog Ser 95: 233-244

Miron G, Boudreau B, Bourget E (1995) Use of larval supply in benthic ecology: testing correlations between larval supply and larval settlement. Mar Ecol Prog Ser 124: 301-305

Miron G, Boudreau E, Archambault P (1996) Scale of observation and distribution of adult conspecifics: their influence in assessing passive and active settlement mechanisms in the barnacle Balanus crenatus (Brugiere). J Exp Mar Biol Ecol 201: 137-158

Morgan, SG, Shanks AL, MacMahn JH, Reniers AJ, Feddersen F (2018) Planktonic subsidies to surf-zone and intertidal communities. Annu Rev Mar Sci $10: 345-369$

Newman WA (1989) Barnacle taxonomy. Nature 337: 23-24

Olivier FO, Tremblay R, Bourget E, Rittschoi D (2000) Barnacle settlement: field experiments on the influence of larval supply, tidal level, biofilm quality and age on Balanus amphirite cyprids. Mar Ecol Prog Ser 199: 185-204

Osman RW, Whitlatch RB (1995a) The influence of resident adults on recruitment: a comparison to settlement. J Exp Mar Biol Ecol 190(2): 169-198 
Osman RW, Whitlatch RB (1995b) The influence of resident adults on larval settlement: experiments with four species of ascidians. J Exp Mar Biol Ecol 190: $199-220$

Paine RT (1966) Food web complexity and species diversity. Am Nat 100(910): $65-75$

Paine RT (1974) Intertidal community structure. Experimental studies on the relationship between a dominant competitor and its principal predator. Oecologia 15(2): 93-120

Paulay G, Boring L, Strathmann RR (1985) Food limited growth and development of larvae: Experiments with natural sea water. J Exp Mar Biol Ecol 93(12): $1-10$

Pawlik JR (1992) Chemical ecology of the settlement of benthic marine invertebrates. Oceanogr Mar Biol Annu Rev 30: 273-335

Pechenik JA, Wendt DE, Jarrett JN (1998) Metamorphosis is not a new beginning. Bioscience 48(11): 901-910

Pfaff MC, Branch GM, Fisher JL, Hoffmann V, Ellis AG, Largier JL (2015) Delivery of marine larvae to shore requires multiple sequential transport mechanisms. Ecology 96: 1399-1410

Pineda J (1991) Predictable upwelling and the shoreward transport of planktonic larvae by internal tidal bores. Science 253: 548-551

Pineda J (1994) Spatial and temporal patterns in barnacle settlement rate along a southern California rocky shore. Mar Ecol Prog Ser 107: 125-138 
Pineda J, Caswell H (1997) Dependence of settlement rate on suitable substrate area. Mar Biol 129: 541-548

Pineda J (1998) Larval transport by internal tidal bores. WHOI Annual Report

Pineda J (2000) Linking larval settlement to larval transport: assumptions, potentials, and pitfalls Oceanography E Pacif 1: 84-105

Pineda J, Hare JA, Sponaugle SU (2007) Larval transport and dispersal in the coastal ocean and consequences for population connectivity.

Oceanography (Wash DC) 20(3): 22-39

Pineda J, Reyns NB, Starczak VR (2009) Complexity and simplification in understanding recruitment in benthic populations. Pop Ecol 51(1): 17-32

Pineda J, Porri F, Starczak V, Blythe J (2010) Causes of decoupling between larval supply and settlement and consequences for understanding recruitment and population connectivity. J Exp Mar Biol Ecol 392: 9-21

Rahman MA, Yusoff FM, Arshad A, Uehara T (2014) Effects of delayed metamorphosis on larval survival, metamorphosis, and juvenile performance of four closely related species of tropical sea urchins (Genus Echinometra). ScientificWorldJournal doi: 10.1155/2014/918028

Raimondi PT (1988) Settlement cues and determination of the vertical limit of an intertidal barnacle. Ecology 69(2): 400-407

Rilov G, Dudas SE, Menge BA, Grantham BA, Lubchenco J, Schiel DR (2008) The surf zone: a semi-permeable barrier to onshore recruitment of invertebrate larvae? J Exp Mar Biol Ecol 361: 59-74 
Rivera A, Weidberg N, Pardiñas AF, González LG, Acuña L (2013) Role of upwelling on larval dispersal and productivity of gooseneck barnacle populations in the Cantabrian Sea: management implications. PLOS: https://doi.org/10.1371/journal.pone.0078482

Roberts CM (1997) Connectivity and management of Caribbean coral reefs. Science 278(5342): 1454-1457

Ross PM (2001) Larval supply, settlement, and survival of barnacles in a temperate mangrove forest. Mar Ecol Prog Ser 215: 237-249

Roughgarden J, Pennington JT, Stoner DS, Alexander S, Miller KM (1991) Collisions of upwelling fronts with the intertidal zone: the cause of recruitment pulses in barnacle populations of central California. Acta Oecologica 12(1): 35-51

Sale PF, Cowen RK, Danilowicz BS, Jones GP, Kritzer JP, Lindeman KC, Planes S, Polunin NVC, Russ GR, Sadovy YJ, Steneck RS (2005) Critical science gaps impede use of no-take fishery reserves. Trends Ecol Evol 20(2): 74-80

Satumanatpan S, Keough MJ (2001) Roles of larval supply and behavior in determining settlement of barnacles in a temperate mangrove forest. J Exp Mar Biol Ecol 260(2): 133-153

Scrosati R, and Heaven C (2007) Spatial trends in community richness, diversity, and evenness across rocky intertidal environmental stress gradients in eastern Canada. Mar Ecol Prog Ser 342: 1-14

Scrosati RA, Ellrich JA (2017) Unimodal relationship between small-scale barnacle recruitment and the density of pre-existing barnacle adults. PeerJ: e3444 
Shanks AL (1986) Tidal periodicity in the daily settlement of intertidal barnacle larvae and a hypothesized mechanism for the cross-shelf transport of cyprids. Biol Bull 170(3): 429-440

Shanks AL, Largier J, Brink L, Brubaker J, Hoof R (2000) Demonstration of the onshore transport of larval invertebrates by the shoreward movement of an upwelling front. Limnol Oceanogr 45(1): 230-236

Shanks AL, Brink L (2005) Upwelling, downwelling, and cross-shelf transport of bivalve larvae: test a hypothesis. Mar Ecol Prog Ser 302: 1-12

Shanks AL (2009) Barnacle settlement vs. recruitment as indicators of larval delivery. II. Time-series analysis and hypothesized delivery mechanisms. Mar Ecol Prog Ser 385: 217-226

Shanks AL, Morgan SG, MacMahan J, Reniers JHM (2017) Alongshore variation in barnacle populations is determined by surf zone hydrodynamics. Ecol Monogr 87(3): 508-532

Smith DL, Johnson KB (1996) A Guide to Marine Coastal Plankton and Marine Invertebrate Larvae, second edition. Kendall/Hunt Publishing Company, Iowa, USA

Starczak V, Pérez-Brunius P, Levine HE, Gyory J, Pineda J (2011) The role of season and salinity in influencing barnacle distributions in two adjacent coastal mangrove lagoons. Bull Mar Sci 87(3): 275-299

Stephenson TA, Stephenson A (1949) The universal features of zonation between tide-marks on rocky coasts. J Ecol 37(2): 289-305 
Swanson RI, Marshall DJ, Steinberg PD (2007) Larval desperation and histamine: how simple responses can lead to complex changes in larval behavior. J Exp Biol 219: 3228-3235

Tapía FJ, Pineda J (2007) Stage-specific distribution of barnacle larvae in nearshore waters: potential for limited dispersal and high mortality rates. Mar Ecol Prog Ser 342: 177-190

Tapía FJ, DiBacco C, Jarrett J, Pineda J (2010) Vertical distribution of barnacle larvae at a fixed nearshore station in southern California: stage-specific and diel patterns. Estuar Coast Shelf Sci 86: 265-270

Tegner MJ, Dayton PK (1991) Sea urchins, El Niños, and the long-term stability of Southern California kelp forest communities. Mar Ecol Prog Ser 77: 49-63

Todd CD (1998) Larval supply and recruitment of benthic invertebrates: do larvae always disperse as much as we believe?. Hydrobiologia 375-376: 1-21

Walters LJ, Hadfield MG, Smith CM (1996) Waterborne chemical compounds in tropical macroalgae: positive and negative cues for larval settlement. Mar Biol 126(3): 383-393

Wethey DS (1983) Geographic limits and local zonation: the barnacles Semibalanus (Balanus) and Chthamalus in New England. Biol Bull 165: $330-341$

Wing SR, Largier JL, Botsford LW, Quinn JF (1995) Settlement and transport of benthic invertebrates in an intermittent upwelling region. Limnol Oceanogr 40(2): $316-329$ 
Wright JR, Boxshall AJ (1999) The influence of small-scale flow and chemical cues on the settlement of two congeneric barnacle specie. Mar Ecol Prog Ser 183: $179-187$

Valencia-Gasti JA, Ladah LB (2016) Synchronous settlement of barnacle larvae at small spatial scales correlates with both internal waves and onshore surface winds. Mar Ecol Prog Ser 552: 195-210

von der Meden CEO, Porri F, Radloff S, McQuaid CD (2012) Settlement intensification and coastline topography: understanding the role of habitat availability in the pelagic-benthic transition. Mar Ecol Prog Ser 459: 63-71 Zaba KD, Rudnick DL (2016) The 2014-2015 warming anomaly in the southern California current system observed by underwater gliders. Geophys Res Lett 43(3): DOI: 10.1002/2015GL067550

Zwerschke N, Bollen M, Molis M., Scrosati RA (2013) An environmental stress model correctly predicts unimodal trends in overall species richness and diversity along intertidal elevation gradients. Helgol Mar Res 67(4): 663674 
APPENDICES 
APPENDIX A. Field deployment of larval traps paired with settlement traps.

Technical display and dimensions of larval traps including segmented funnel ending in $100 \mu \mathrm{m}$ sieve. 
APPENDIX A
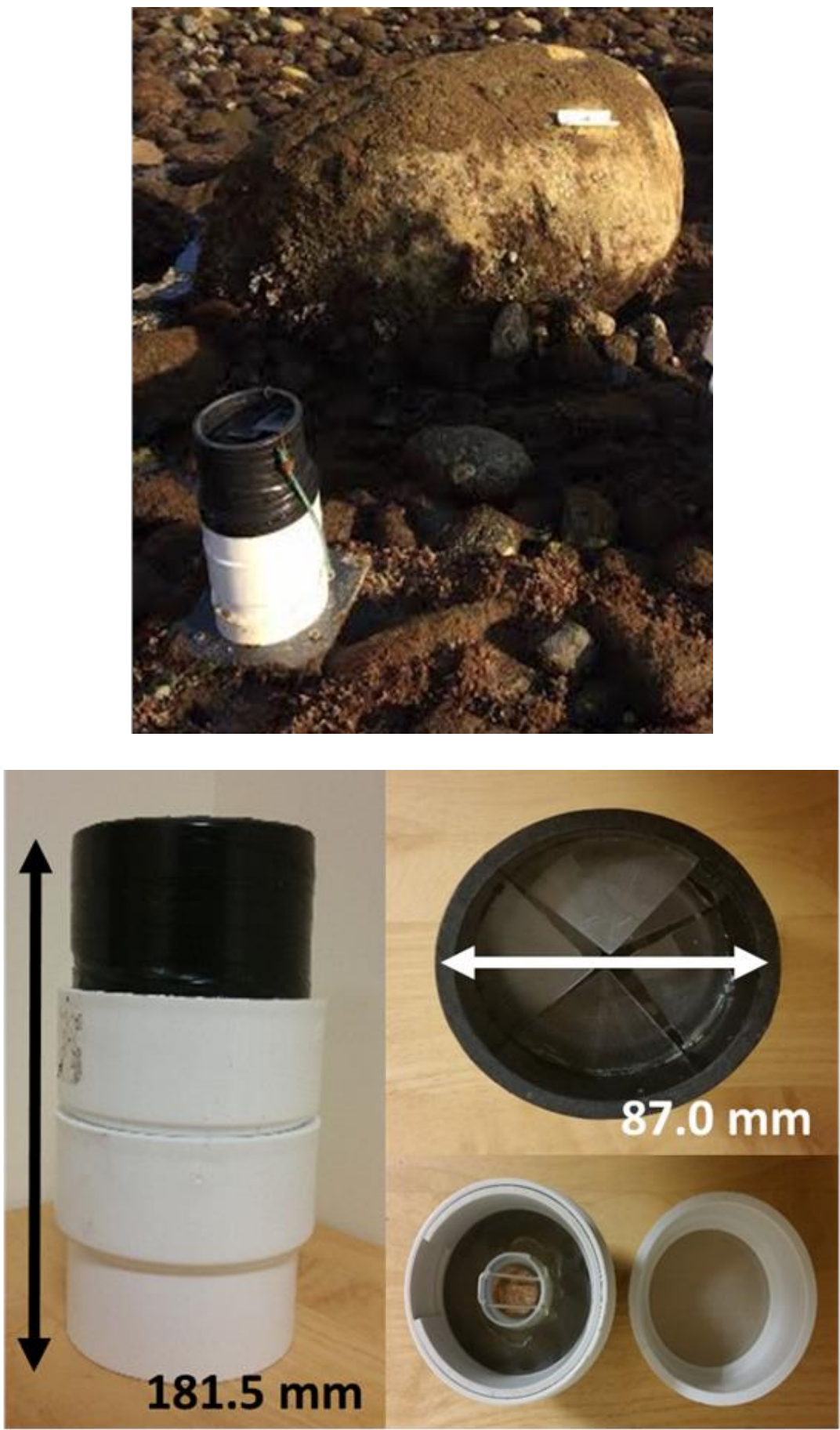
APPENDIX B. Elevations (with respect to MLLW) for both the larval supply traps and the settlement plates across pairings used throughout the timeline of sampling. 
Pair Label Trap Elevation Plate Elevation
1
0.382
0.429
2
0.385
0.482
3
0.385
0.583
7
0.398
0.444
8
0.432
0.322
9
0.411
0.410
12
0.426
0.408
14
0.422
0.479 
APPENDIX C. Field deployment of the settlement plates. Dimensions and specifications of plates where individuals were counted along the seam of each of the 3 grooves. Examples of the individuals sampled are pictured from right to left: Chthamalus fissus metamorphs, cyprids, and Balanus glandula metamorphs. 
APPENDIX C
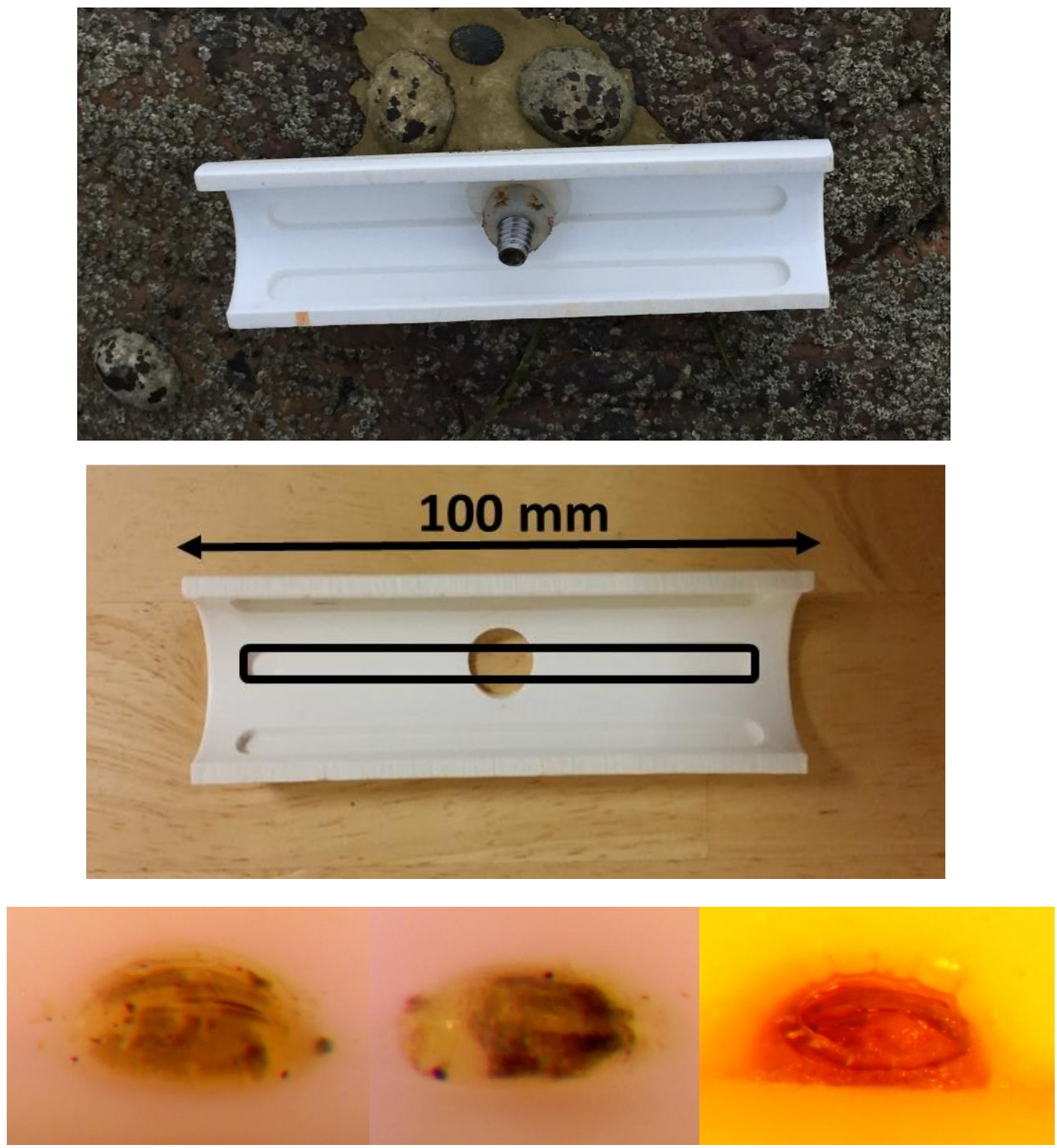
APPENDIX D. Set-up for adult population / habitat surveys which included sampling a quadrat at each of the 14 plate locations, then through transect, random selection, we sampled three additional quadrats north, west, and east of each plate rock to quantify the \% cover categories listed. 


\section{APPENDIX D}

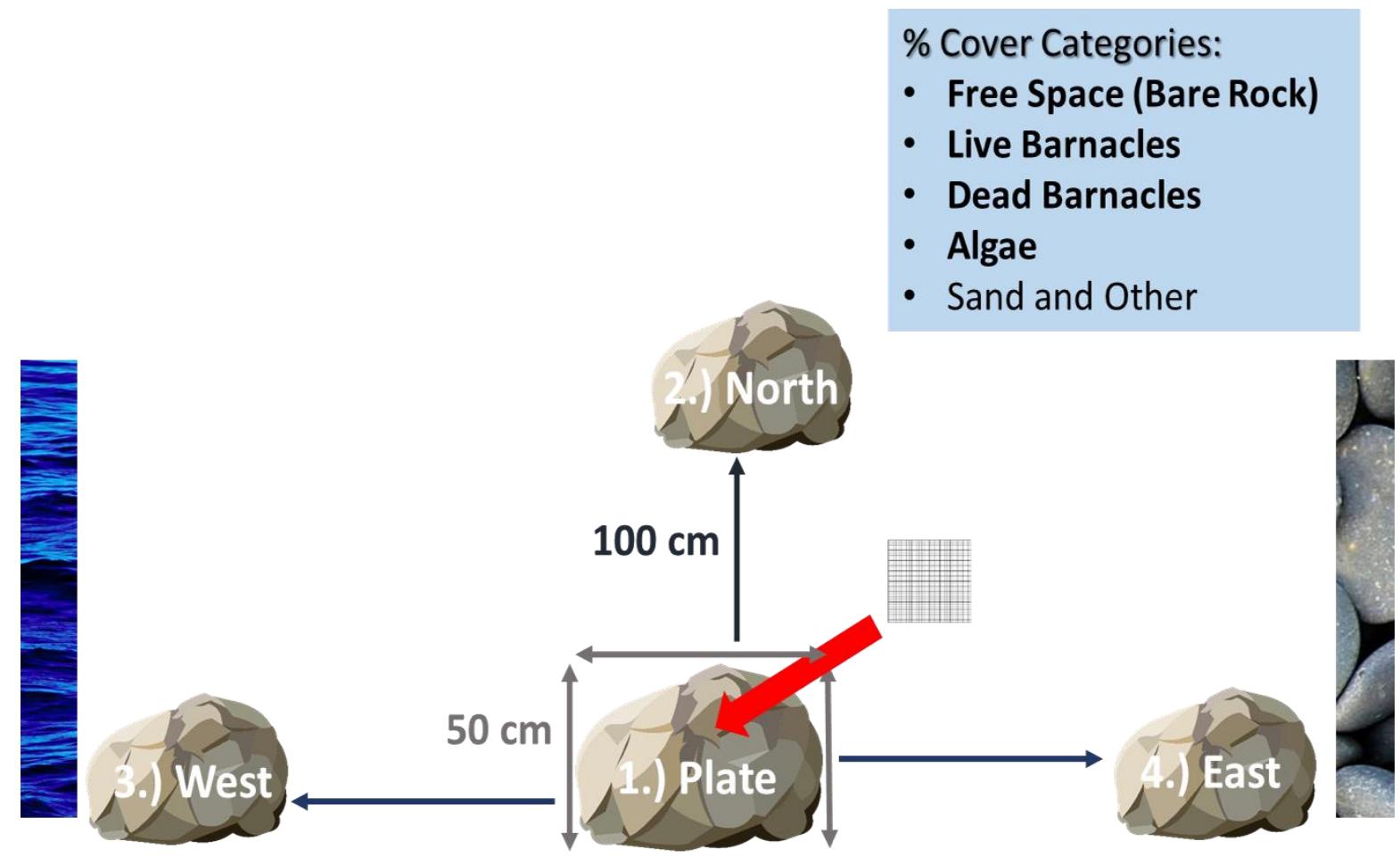


APPENDIX E. Initial exploration of the interaction between measures of intertidal hydrodynamics (significant wave height and sediment volume) and its interaction with larval supply either by Spring-Summer period (2014 vs. 2015) or sample period (2014, 2015a, and 2015b). 


\section{APPENDIX E}

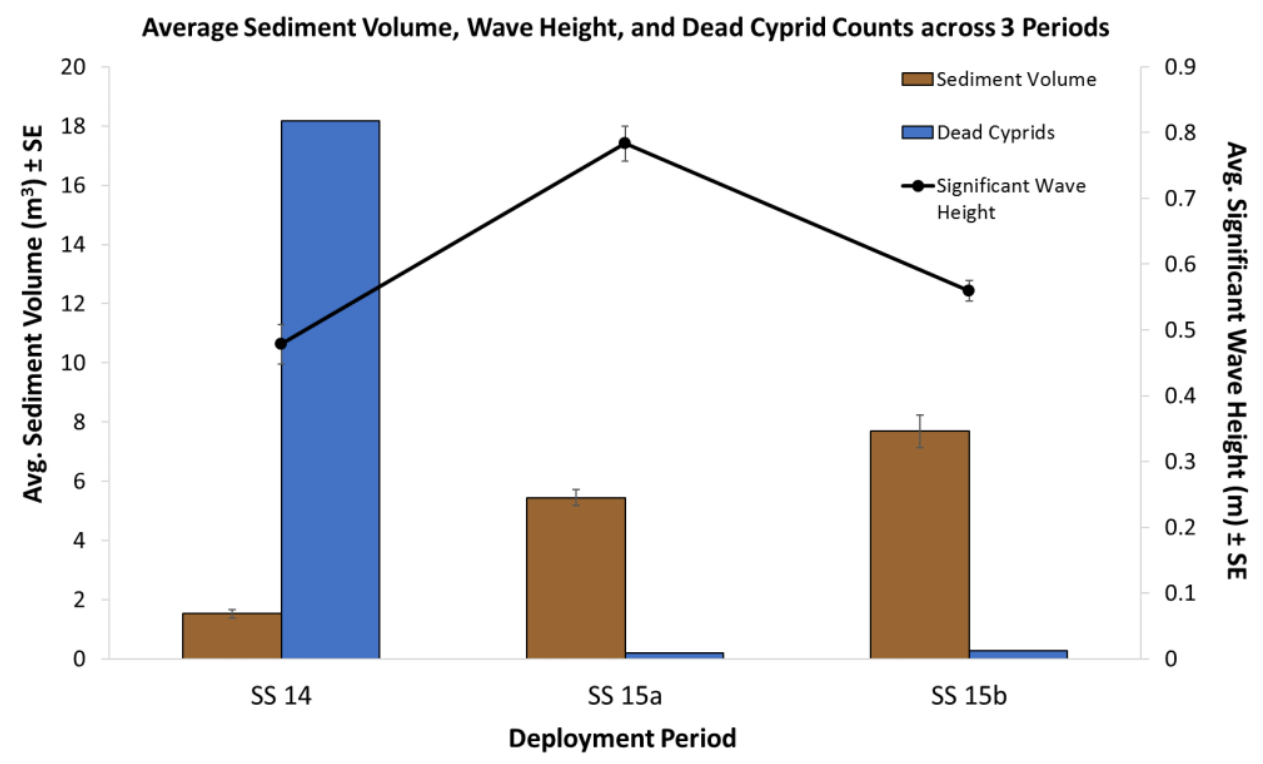

Average Sediment Volume, Wave Height, and Dead Cyprid Counts across Spring-Summer 2014 vs. 2015

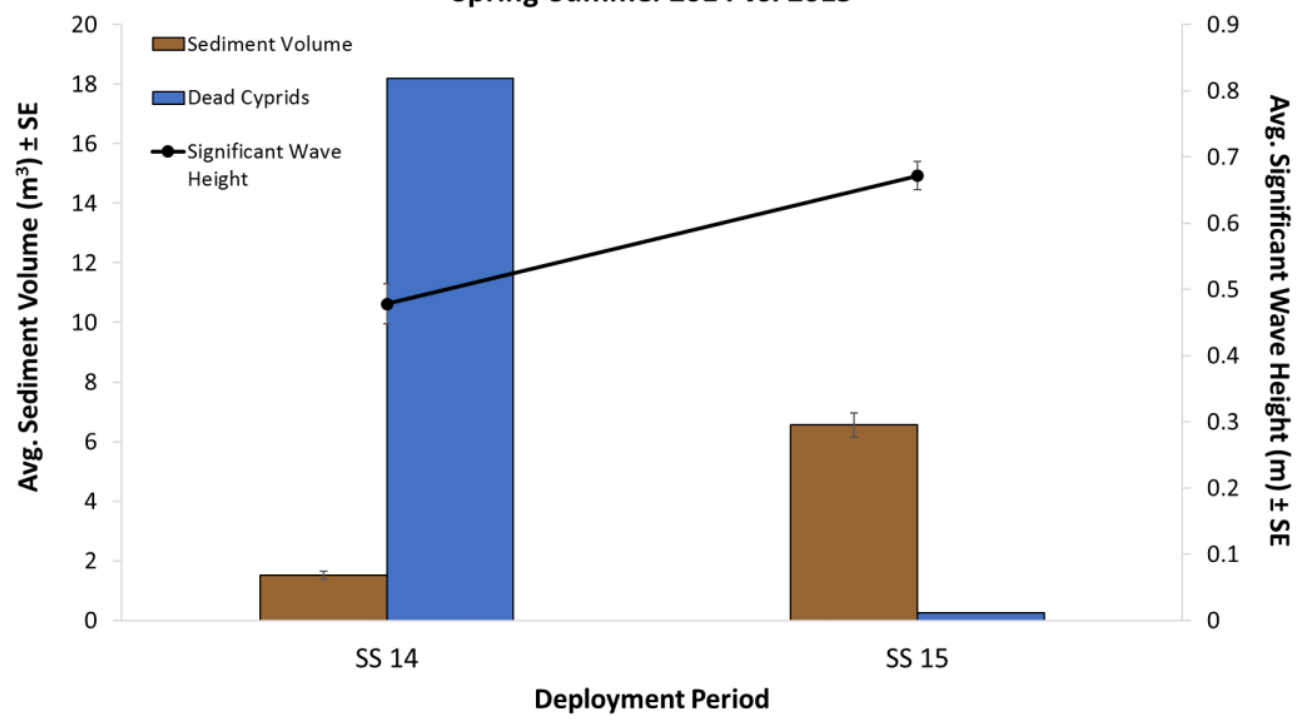


APPENDIX F. Initial figure to analyze the potential interaction between significant wave height and sediment volume to understand the role of microhydrodynamics in larval transport which further shapes benthic invertebrate (i.e. barnacle: Chthamalus fissus) settlement within the rocky intertidal. 


\section{APPENDIX F}

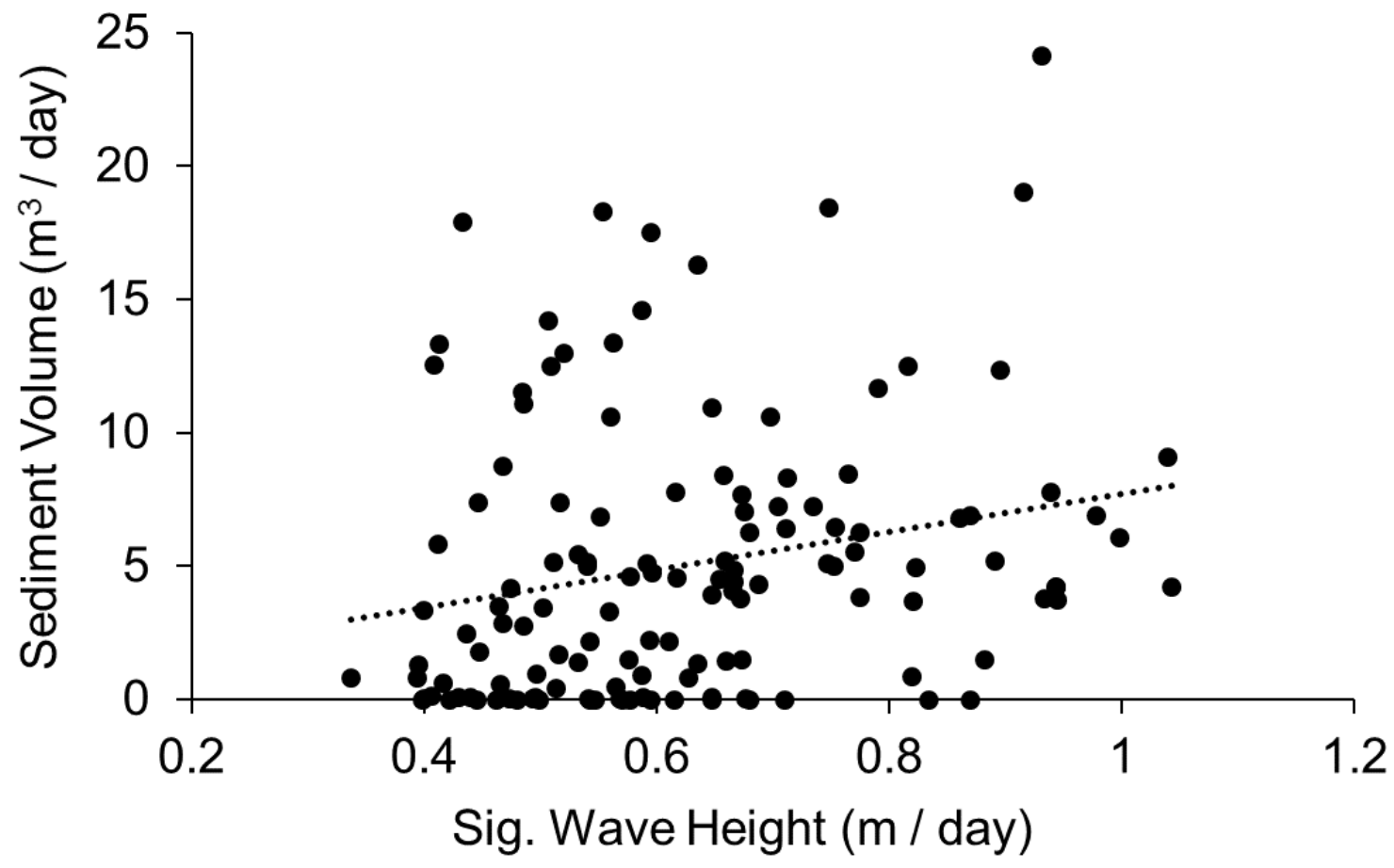

